\title{
Close-Range Sensing and Data Fusion for Built Heritage Inspection and Monitoring-A Review
}

\author{
Efstathios Adamopoulos ${ }^{1, *(D)}$ and Fulvio Rinaudo ${ }^{2}(\mathbb{D}$ \\ 1 Department of Computer Science, University of Turin, Corso Svizzera 185, 10149 Torino, Italy \\ 2 Department of Architecture and Design, Polytechnic University of Turin, Viale Pier Andrea Mattioli 39, \\ 10125 Torino, Italy; fulvio.rinaudo@polito.it \\ * Correspondence: efstathios.adamopoulos@unito.it
}

Citation: Adamopoulos, E.; Rinaudo, F. Close-Range Sensing and Data Fusion for Built Heritage Inspection and Monitoring-A Review. Remote Sens. 2021, 13, 3936. https://doi.org/ $10.3390 / \mathrm{rs} 13193936$

Academic Editor: Giuseppe Casula

Received: 1 August 2021

Accepted: 28 September 2021

Published: 1 October 2021

Publisher's Note: MDPI stays neutral with regard to jurisdictional claims in published maps and institutional affiliations.

Copyright: () 2021 by the authors. Licensee MDPI, Basel, Switzerland. This article is an open access article distributed under the terms and conditions of the Creative Commons Attribution (CC BY) license (https:// creativecommons.org/licenses/by/ $4.0 /)$.

\begin{abstract}
Built cultural heritage is under constant threat due to environmental pressures, anthropogenic damages, and interventions. Understanding the preservation state of monuments and historical structures, and the factors that alter their architectural and structural characteristics through time, is crucial for ensuring their protection. Therefore, inspection and monitoring techniques are essential for heritage preservation, as they enable knowledge about the altering factors that put built cultural heritage at risk, by recording their immediate effects on monuments and historic structures. Nondestructive evaluations with close-range sensing techniques play a crucial role in monitoring. However, data recorded by different sensors are frequently processed separately, which hinders integrated use, visualization, and interpretation. This article's aim is twofold: i) to present an overview of close-range sensing techniques frequently applied to evaluate built heritage conditions, and ii) to review the progress made regarding the fusion of multi-sensor data recorded by them. Particular emphasis is given to the integration of data from metric surveying and from recording techniques that are traditionally non-metric. The article attempts to shed light on the problems of the individual and integrated use of image-based modeling, laser scanning, thermography, multispectral imaging, ground penetrating radar, and ultrasonic testing, giving heritage practitioners a point of reference for the successful implementation of multidisciplinary approaches for built cultural heritage scientific investigations.
\end{abstract}

Keywords: nondestructive evaluation; metric survey; sensors; close-range sensing; data fusion; building inspection; cultural heritage

\section{Introduction}

The maintenance and conservation of historic structures are elaborate tasks filled with challenges. Geometrical complexity, multiplicity, and degradation of materials, varying historical construction techniques, and a plethora of other intrinsic and extrinsic factors-including environmental pressures and past anthropogenic interventions-induce problems (regarding protecting the built environment). Therefore, extensive knowledge of these parameters is required to ensure the effectiveness of implemented interventions. Thus, comprehensive condition inspections of built cultural heritage are necessary to holistically address the state of preservation (facilitating the diagnostic process) and understand the prevailing problems of historical structures that place them at risk. Furthermore, monitoring the state of preservation through time is fundamental towards effectively interpreting the occurring degradation phenomena and, therefore, a powerful tool for the decision-making process regarding built heritage protection.

Systematic nondestructive acquisition and integrated handling of multisource scientific data play essential roles in documenting the state of preservation of historic structures [1]. The need for multidisciplinary inspection methodologies is frequently noted in the literature, mainly in application cases of built cultural heritage of outstanding value, 
present extensive deterioration or increased risks [2-4]. Likewise, the non-destructiveness of monitoring methods has been highlighted as an important factor for safeguarding the conditions of significantly deteriorated, or already at risk, historic structures [5,6]. Hence, active and passive nondestructive sensing techniques and appropriate signal processing methods are regularly used as nondestructive sources of multidisciplinary data useful for inspection and monitoring applications.

Close-range sensing-based methods (including techniques for geometric recording) employed for built heritage surveys are often considered as separate practices. However, their integration enhances the interpretation of the state of preservation, as many evaluation methods can act complementarily [7-12]. We should also note that imparting spatial properties to nondestructive evaluation methods allows for better interpretation and visualization of the state of preservation, while facilitating the spatial fusion of multisensor data [13-15]. At the same time, monitoring benefits from geometric recording methods (i.e., by acquiring spatial data and utilizing valuable sensing metadata derived from employed measurement instrumentation).

Recognizing the importance of the historical built environment's sustainability, and the contribution of implementing multi-sensor approaches for non-destructive surveys of historic structures as part of the protection process, this paper presents a review of close-range sensing methods for inspecting and monitoring their state of preservation. Therefore, this review focuses on state-of-the-art non-destructive techniques for active and passive recording, as well as, the fusion of multi-wavelength data acquired from their implementation. Following a comprehensive mention of the contemporary proximal sensing techniques employed for reality capture and nondestructive evaluation for built heritage structures-including their basic operating principles and application scenarios- the processes and levels of data fusion methodologies encountered in recent literature are outlined. Furthermore, the advantages and limitations of individual close-range sensing techniques and multi-sensor data fusion strategies are highlighted (and some direct perspectives are attempted).

\section{Close-Range Sensing Technologies}

Rapid advances in sensor and information processing technologies have, in recent years, provided powerful geometric documentation tools that facilitate surveying, modeling, and monitoring of architectural heritage [16,17]. These technological solutions include equipment for metric data acquisition, such as total stations, laser scanners, Global Navigation Satellite System (GNSS) receivers, imaging sensors, software for processing, managing, visualizing, and disseminating the recorded data and their derivative products, and computer hardware for running the software $[18,19]$. The technical developments in photogrammetry-based and scanning-based reality capturing have allowed for easy-to-use instrumentation, automatized three-dimensional (3D) shape reconstruction, and color texturing methodologies for documenting the conditions of historic structures, which enables monitoring and on-site inspections [20,21]. An equally important advantage of these advancements is that, through the generation of high-fidelity 3D models and point clouds, they have allowed for virtual fruition-remote inspection, maintenance management, and valorization via mobile and web-based platforms that utilize smart algorithms, augmented reality, and spatially aware content [22-29].

The integration of geometric recording methods is often considered in order to overcome the limitations imposed by individual techniques [30-35]. Selecting the appropriate methodologies for reality-based documentation (sensors, hardware, software) and data processing procedures, designing production workflows that involve heterogeneous recorded data, and assuring that the final result is in accordance with all of the given technical specifications poses significant challenges [36]. The application of different geomatics techniques interrelates with the complexity and size of the heritage structure, but is actually determined by numerous factors, such as portability of available instrumentation, 
personnel experience, budget, accuracy specifications, and the integrability of recording methods [37-40].

Alongside the advancements in reality capturing, significant technological developments have taken place in the field of (historic) material nondestructive testing (NDT) and evaluation. Non-destructive inspection techniques operating at the visible, infrared, microwave, and radio-wave frequencies, have become more versatile and cost-effective and, therefore, have been increasingly used in many fields, with innovation and development primarily being driven by industry. NDT sensors have different advantages and limitations depending on their operating principles and spectral ranges, but, nevertheless, the continuous innovation and development of portable and compact devices will have a major role for future NDT instruments as these can facilitate the decision-making processes through agile on-site inspections [41,42].

\subsection{Laser Scanning}

Laser scanning methods are based on active recording techniques; they emit radiation through their own sources and record the backscatter, instead of sensing the reflected radiation originating from other sources. Terrestrial laser scanning (TLS) instruments utilize light detection and ranging (LiDAR) for range measurements and an optical beam deflection mechanism to record angle measurements. Depending on their operating principles, which vary significantly, the use of TLS techniques for build heritage recording poses different advantages and limitations [43,44]. Laser scanning mechanisms generally enable dense measurements, capturing in accurate and fast manners, and are (relatively) easily operated. In a conventional laser-scanning instrument, the scanner measures, stepwise, the surrounding scene with a fast vertical mirror rotation, and a slower horizontal instrument rotation. More specifics on the scanning mechanisms and measuring techniques of TLS can be found in Beraldin et al. [45], and Petrie and Toth [46].

TLS describes a variety of measuring instrumentation, sometimes integrated with a digital camera that provides color information to the measured point cloud. TLS has experienced a rapid decrease in the size, weight, and price of sensors, and a constant increase in measurement speed and spatial resolution. These rapid improvements allow measuring up to 1 million points per second at the range of 100-300 m with ranging precision at the millimeter level, at a relatively low price. However, TLS sensors are lineof-sight and, therefore, multiple scans are required to scan an entire structure's surface (Figure 1). The implementation of TLS means that, in ideal conditions of calibration, the captured point clouds do not need to be scaled, such as photogrammetric models. There are two typologies of TLS instrumentation widely used for cultural heritage documentation, operating on different recording principles:

- $\quad$ Time-of-Flight (ToF) scanners measure distances, by measuring the time difference between the emitted laser pulse and the received backscatter. These devices are characterized by lower acquisition speeds and accuracies $(5-6 \mathrm{~mm})$, but are mainly suited for long-range acquisition.

- $\quad$ Phase Shift (PS) scanners record the difference of phase between the emitted and backscattered signal (sinusoidal wave patterns) of continuous laser pulses. These devices are characterized by shorter ranges (up to $300 \mathrm{~m}$ ) and provide better accuracy compared to ToF scanners $(2-3 \mathrm{~mm})$; thus, they are suited for documentation at large scales. 


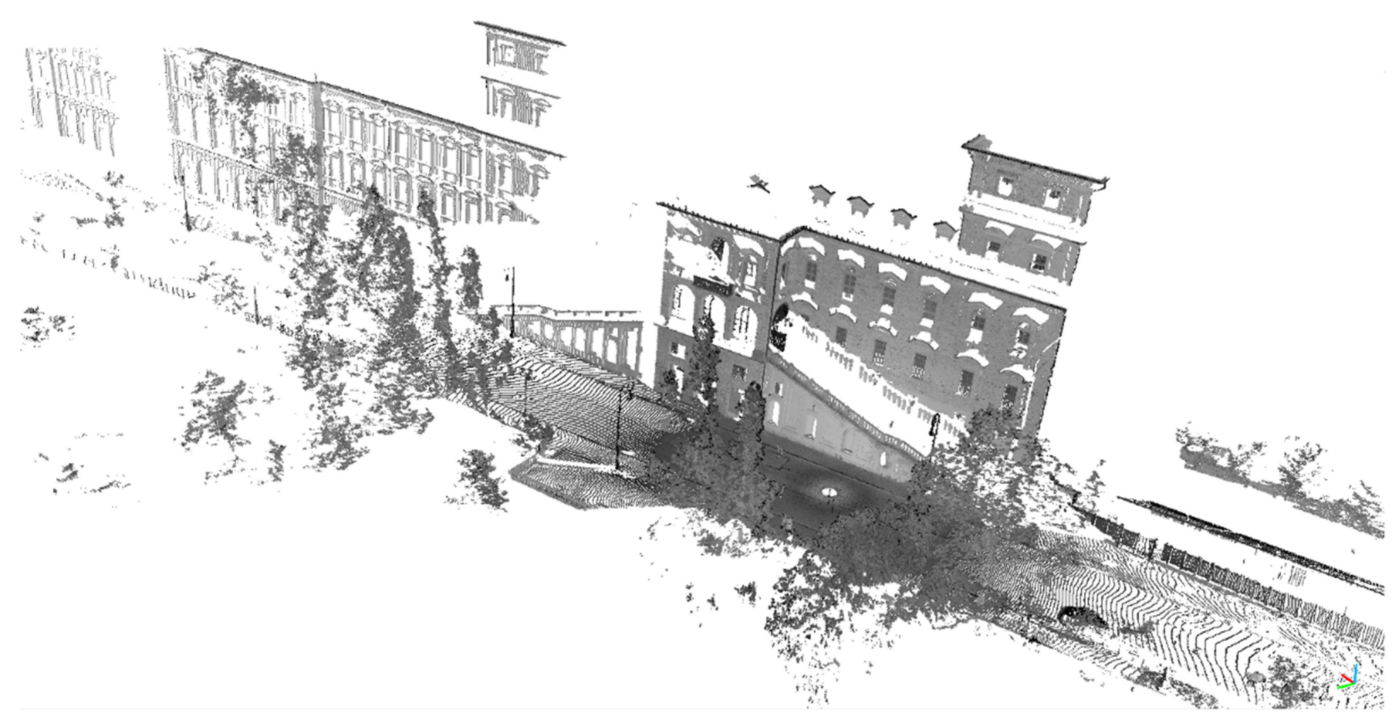

Figure 1. Point cloud of Castello del Valentino in Turin (Italy) obtained from a single scan.

Table 1 presents a brief comparison between TLS devices.

Table 1. Terrestrial laser scanning instruments.

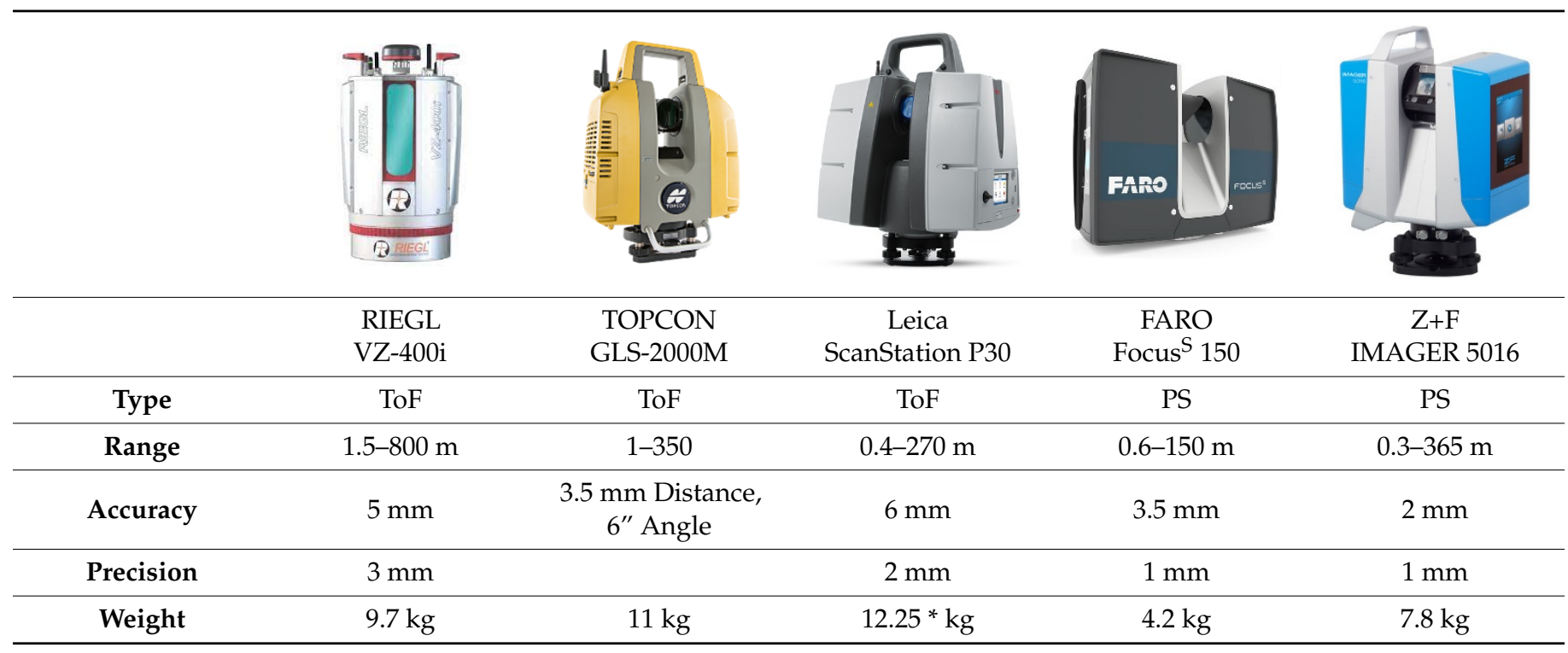

Note: *w/o batteries; ToF: Time-of-Flight; PS: phase shift

Recording with TLS presupposes planning the data acquisition campaign to identify the elements or surfaces to be covered, determine the optimal number and location for scanning positions and targets, and the management process of the point clouds $[38,43,47,48]$. Optimally placed scanning positions are selected to maximize cover and incidence angles, achieving the required resolution specifications, while decreasing occlusions and, if possible, the number of scans/scanning time [49]. Targets are positioned in overlapping areas to facilitate registration between scans. Maintaining a substantial spatial distribution of scan targets on the $x-y$ plane and at the $z$-direction is essential to avoid multiplicity of solutions when solving the orientation between scans. Depending on the registration method between point clouds from different scanning positions, at least four correctly distributed targets at xyz should be positioned [50]. Registration between measured point clouds is usually performed through a coarse transformation based on common, often artificial, targets followed by a fine registration method-which mainly refers to the itera- 
tive closest point (ICP) algorithm [51-53]. Other fine registration methods for TLS point clouds include random sample consensus (RANSAC), normal distribution transform, and methods using auxiliary data, such as target imagery and measurement-device location GNSS coordinates [54,55].

Regarding the documentation of historic structures, TLS devices have been successfully employed for high-fidelity reality-based modeling of numerous large and geometrically complex monuments [56-59]. However, the use of ToF scanning devices has become less frequent, although it is preferred for long-range applications (e.g., monitoring the erosion of historical mine remains [60]), and is used in applications that require acquisition from variable ranges, in combination with PS scanners [61-63]. Nevertheless, the possibility of directly geo-referencing point clouds through the integration of ToF scanners and GNNS measurement systems provides a powerful 3D recording solution [64].

Both ToF and PS scanners are extensively used for deformation monitoring of historic structures. The geometric deformations are estimated by comparing measured point clouds with an idealized shape [65-73] or by performing multitemporal measurements [74-77]. Furthermore, laser scanning appears to be particularly suitable for obtaining the necessary geometric data to generate numerical models for structural health analysis, in terms of rapidity and spatial resolution [78-82].

TLS is, moreover, a source of important radiometric data, exploitable, to facilitate nondestructive condition documentations further. For example, reflectivity values recorded by TLS, which express the intensity of the backscattered laser energy, have been recently explored for mapping the alterations of historical surfaces [83-86] as well as for surface moisture detection [87-89]. However, to assure the usefulness of intensity data collected by TLS, rigorous radiometric calibrations are required to eliminate the effects of data acquisition geometry, instrumental errors, environmental effects, and reflectivity characteristics of the target [90-92].

\subsection{Photogrammetric Techniques}

Digital close-range photogrammetry involves techniques for retrieving 3D information from two-dimensional digital images recorded under controlled illumination conditions. The advancements in dense image matching [93] and the improvements in camera sensor manufacturing [94] have drastically improved image-based modeling (IBM), allowing the generation of dense point clouds, textured models, and high-resolution ortho-mosaics from large datasets. Up-to-date IBM approaches are based on photogrammetric computer vision algorithms. They are affordable, generally robust, and agile, considering implementation and flexibility of the ground-sampling distances (GSD) and other parameters that can be adjusted according to the specified requirements $[95,96]$. In addition, these approaches allow the use of non-metric and lower-end cameras, and have widened the application scope of photogrammetry for built cultural heritage (because of their increased automatization and the level of detail they can record).

Multi-view IBM refers to digitization approaches similar for the production of point clouds and 3D models from datasets of overlapping images, using automated algorithmic methods [97]. Standard multi-view 3D reconstruction pipelines start with detecting and describing salient features on every image of a dataset. The features are matched across different image pairs, and false matches are filtered out. Next, Structure-from-Motion (SfM) implementations are needed to estimate the interior and exterior orientations for the cameras, combining all relative orientations of the image pairs at a local coordinate system without an absolute scale. Then, each image's relative position and orientation in every pair is calculated using triangulation, and the combined image block is optimized through bundle adjustment. The resulting sparse point cloud is further densified by employing dense image matching algorithms, and most points of the scene are reconstructed in a procedure typically called multi-view stereo (MVS). The dense point cloud is meshed into a 3D model, usually utilizing Delaunay triangulation algorithms, and textured by interpolating color information from the image dataset. Multi-view image-based recording 
approaches in principle do not require the implementation of control points with known coordinates to function. Nonetheless, the use of control points with known coordinates during the orientation improves the accuracy of the results, and is mandatory for acquiring measurements or for geo-referencing the 3D models.

The IBM pipelines can effectively involve oblique imagery and require low levels of supervision and user expertise, making them extremely popular for digitizing the historic built environment. Many studies report the application of IBM workflows for documenting monumental architecture [98-103] (Figure 2) and other historical constructions [104-107], often supporting the implementation of failure analysis through numerical modeling. In any case, IBM is seldom considered as a stand-alone solution for nondestructive evaluation of historical structures [108-110], in all likelihood due to the higher cost-effectiveness of TLS to produce large-volume models suitable for deformation monitoring. Nevertheless, IBM provides a rich in information background for the thematic mapping of historic structures' deterioration [111,112], necessary for calculating damage/risk indexes [113].
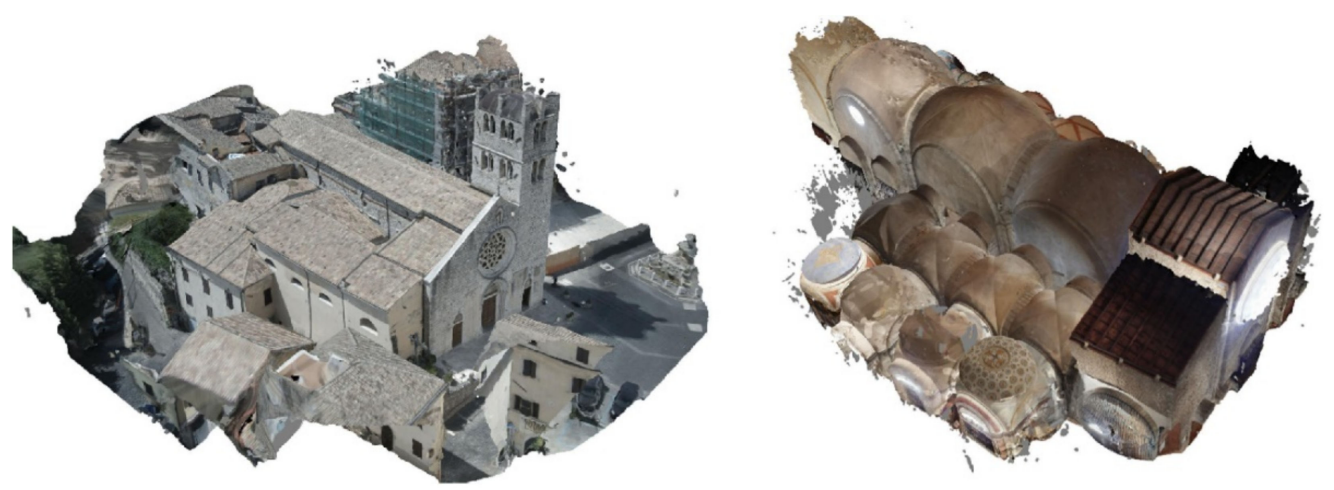

Figure 2. High-density point cloud with applied texture of the: (left) exterior and (right) interior of the church of Santa Maria Maggiore [101].

\subsection{Infrared Thermography}

Infrared thermography (IRT) is a close-range sensing technique well established for inspection and monitoring of structures. IRT is a noncontact and noninvasive technique that allows repeatability, prolonged use, and comparison between areas of the target and multitemporal application; thus, presenting many advantages over other nondestructive evaluation technologies [114,115]. Through thermal detectors, it measures levels of emitted infrared radiation at the long-wavelength infrared (LWIR) portion $(7-14 \mu \mathrm{m})$ of the electromagnetic spectrum [116]. Infrared radiation is emitted from all materials, at temperatures above absolute zero (i.e., $\mathrm{T}>-273.15^{\circ} \mathrm{C}$ ), due to their molecules' mobility. This infrared motion increases at higher material temperatures and reduces at lower temperatures. Therefore, the intensity, frequency, and wavelength of infrared radiation depend on the temperature and magnitude of the source and the material's emissivity [117].

A thermal camera is a device employing a thermal-infrared detector that records the radiant energy - at the LWIR range - that falls onto the camera lens and converts it to a measurable form (Figure 3). Using a radiation detector, the thermal camera displays a target's temperature, creating a visual representation, a two-dimensional thermal image from the detected average of incoming radiative energy intensities [118].

A few fundamental parameters affect the performance of the thermal camera's sensor and, subsequently, the image quality. They are sensor spectral range, or spectral response; spatial resolution, or pixel pitch; thermal sensitivity, or equivalent random noise level; intensity resolution, or the number of intensity levels; scan speed, or update rate of the scanning mechanism [119]. The spectral range refers to the portion of the infrared spectrum in which the camera will be operationally active. Sensitivity is measured in Celsius degrees and reflects the minimum detectable temperature difference. Inspectionpurposed temperature sensors with good sensitivity recognize temperature differences of 
even $0.040{ }^{\circ} \mathrm{C}$ (uncooled cameras). The intensity resolution is proportional to the number of hues or shades on the thermal camera screen. The higher the resolution, the more smoothly temperature changes will occur. If a target has sudden temperature changes, it will be due to the target itself and not the camera. The spatial resolution of thermography cameras is significantly lower than optical cameras [120].

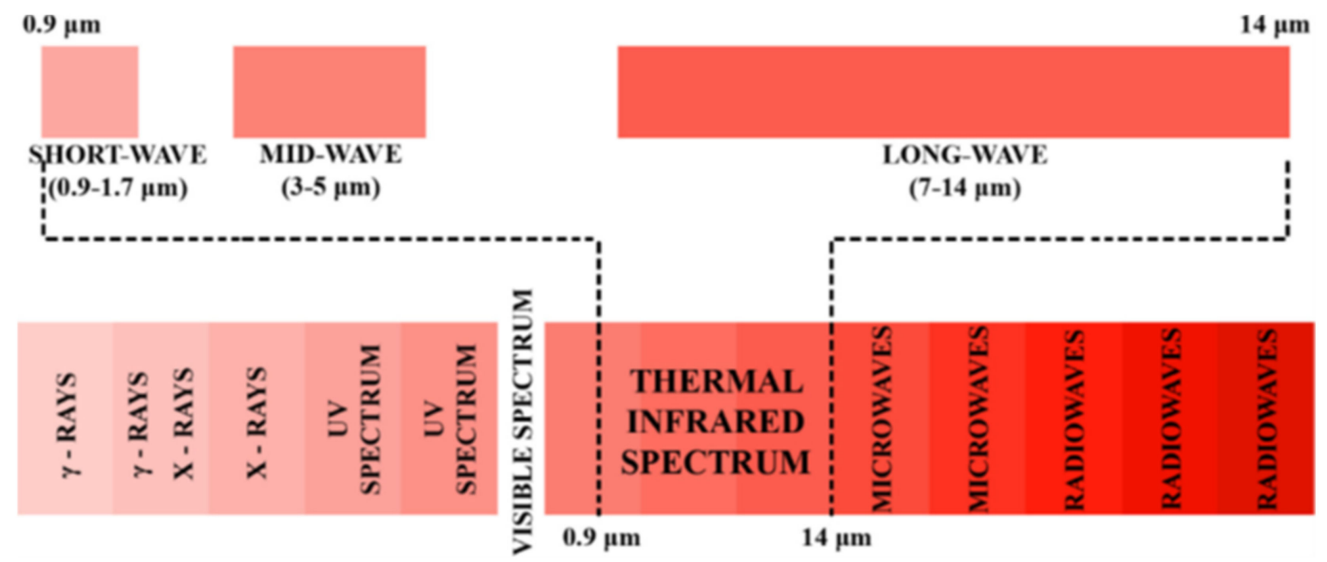

Figure 3. Detailed representation of the thermal infrared spectrum [119].

Recently, affordable thermal camera models have come into the market, including smartphone-adjustable low-resolution instruments [121,122]. However, these inexpensive cameras provide lower accuracy, which makes them unusable for some applications. Table 2 presents some standard thermal cameras purposed for infrastructure inspection available in the market.

Table 2. Thermal cameras for building inspections.

\begin{tabular}{|c|c|c|c|c|c|}
\hline & Avio InfReC R450 & FLIR T840 & FLIR T540 & Fluke TiX580 & Seek ShotPRO \\
\hline Resolution & $480 \times 360$ & $640 \times 480$ & $464 \times 348$ & $640 \times 480$ & $320 \times 240$ \\
\hline FOV $^{1}$ & $14^{\circ} / 24^{\circ} / 48^{\circ}$ & $14^{\circ} / 24^{\circ} / 42^{\circ}$ & $14^{\circ} / 24^{\circ} / 42^{\circ}$ & $12^{\circ} / 34^{\circ} / 48^{\circ}$ & $52^{\circ}$ \\
\hline NETD $^{2}$ & $<25 \mathrm{mK}$ & $<30 \mathrm{mK}$ & $<50 \mathrm{mK}$ & $<50 \mathrm{mK}$ & $<70 \mathrm{mK}$ \\
\hline Accuracy & $2 \%$ & $2 \%$ & $2 \%$ & $2 \%$ & $2 \%$ \\
\hline Range & $8-14 \mu \mathrm{m}$ & $7.5-14 \mu \mathrm{m}$ & $7.5-14 \mu \mathrm{m}$ & $7.5-14 \mu \mathrm{m}$ & $7.5-14 \mu \mathrm{m}$ \\
\hline
\end{tabular}

The typical way of displaying thermal images through a device or computer is generally either a black-and-white image or a colored image, where each color correlates with a temperature range (Figure 4). Thermal images are essentially a mapping of the distribution of infrared radiation, which originates from the different parts of the object. It is also possible to depict isothermal curves, which are lines at the boundary between two colors that reflect points with the same temperature. The thermal image processing software can provide heat profiles, temperature frequency histograms in each area, temperature differences from different images, points with maximum and minimum temperatures, magnifications, and filtering. Nevertheless, thermal infrared images can be difficult to interpret. 

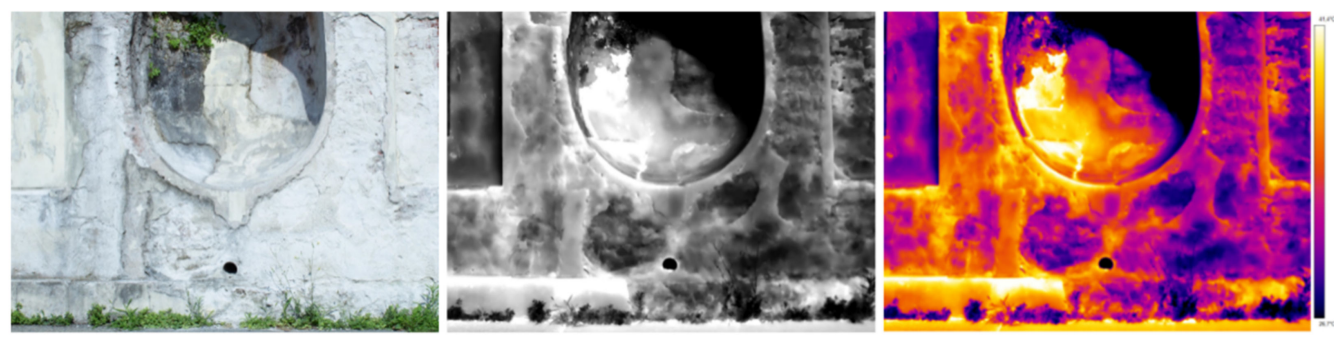

Figure 4. Color image and corresponding thermographic image (grey and iron color pallet) captured at Turin's Castello del Valentino (Italy) riverside façade.

To obtain high quality and useful thermographic data, it is usually necessary to take into account the prevailing conditions (ambient temperature, relative humidity, recording distance, materials emissivity factor) to adjust the camera, eliminating the noise errors they cause in measuring the temperature changes of a target's surface $[123,124]$. For this reason, IRT should be used in controlled environments. Furthermore, the thermal infrared images are, generally, noisy and suffer from a low signal-to-noise ratio. Consequently, several digital image processing (DIP) procedures are employed to enhance acquired thermal images (Figure 5). For image enhancement reasons, a variety of point operation algorithms, such as contrast stretching and histogram equalization, can be applied [125]. The objective of these algorithms is to widen the histogram of an image, which increases the dynamical range, thereby enhancing contrast. Using advanced signal analysis techniques like thermographic signal reconstruction (TSR) and principal component analysis (PCA), defects of greater depths can be detected with higher thermal contrast. Furthermore, feature extraction from thermal images, based on the temperature values, has been observed to be advantageous in moisture, decay, and thermal leaks classification. For the detection of hot spots, image classification and thresholding are performed. Overall, several image segmentation techniques are used on thermal images, and the selection between them depends on the application and the nature of the thermographic acquisition [126].
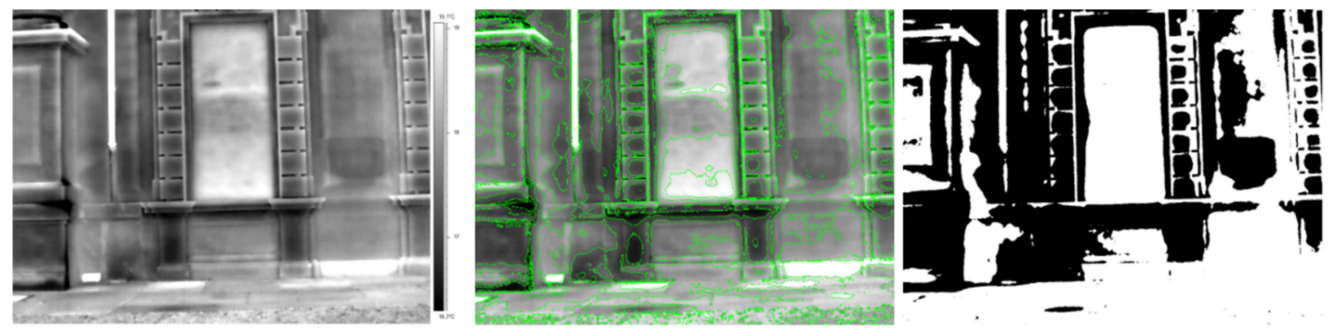

Figure 5. Thermographic image elaboration for Turin's Castello del Valentino (Italy): (left) original thermogram; (center) thermal contours (every $0.5^{\circ} \mathrm{C}$ ); (right) thresholded thermogram $\left(\right.$ at $17.7^{\circ} \mathrm{C}$ ).

IRT records the thermal radiation emitted from surfaces, enabling the analysis of surface temperature patterns, to reveal existing anomalies. In other terms, thermography aims to identify surface areas of interest by observing local temperature differences using thermal sensors [127]. In IRT, two different approaches are employed: active and passive [128]. In active IRT, the target is subjected to thermal stimulation by an external radiation source. The heat propagation depends on the materials' thermal properties and subsurface irregularities resulting in temperature differences on the target's surface. In this scenario, measured thermal radiation comes from the thermal response of the target to the external excitation. This technique is applied in cases where the target is in thermal equilibrium and does not show surface temperature differences or if they are so small that they cannot be detected with passive testing [129]. Given the ability to control the intensity of the external energy source, the artificial thermal excitation can reach deeper into the object, and hence information can be obtained from more internal layers. 
Successful application of active thermography requires that the targeted surface is more or less homogeneous (has a defined high emissivity and, thus, low reflectivity), and that a good knowledge exists about the radiation coming from additional sourcesdirect or indirect (reflected) - and other environmental factors that may affect the measurements [130]. This suggests inherent difficulties in applying active IRT for historical structures, especially for cases of highly deteriorated architectural elements and, thus, less frequent use.

Passive IRT measures the thermal radiation emitted from the target's surface without external heat stimulation. Passive thermography is a technique often employed for building inspections when measuring temperature differences is a factor for evaluating an existing structure's preservation state (or energy performance) [131]. The documentation of irregular temperature distributions on a building's façade or structural elements may assist in detecting potential problems or damages by estimating surface temperature changes compared with assigned reference values [132-134]. New critical developments in thermal measuring device technology, combined with other advantages stemming from its nondestructive nature, have led to widespread application on structural surveys of monumental and historic architecture [135-139]. Moreover, the applications of passive IRT concerning the investigation of historic buildings include the localization of original and replacement materials [140-142], evaluation of the plaster conditions [143-146], assessment of cracks $[137,147,148]$, characterization of material loss-induced features, and other alterations on architectural surfaces [139,149-151], detection of moisture [152-156], localization of concealed defects and subsurface construction [157-159], in addition to evaluation of restoration and consolidation interventions [2,160]. Increased demand is also reported regarding the inspection of masonry arc bridges since their periodical inspection can be difficult due to access restrictions, which necessitates the application of remote sensing techniques [161-163].

\subsection{Multispectral Imaging}

Multispectral image acquisition is primarily associated with capturing data with a single imaging sensor capable of recording at multiple electromagnetic spectrum bands. Materials have specific spectral signatures at different regions of the electromagnetic spectrum, which can be obtained under controlled conditions [164]. Surface defects caused by weathering, concentration of moisture, and other alterations change their normal and homogeneous spectral behavior. Therefore, capturing spectral anomalies with imaging sensors facilitates identifying these characteristics. However, acquiring useful data of damages of historical structure surfaces poses considerable challenges, such as selecting the proper sensors, radiometrically and geometrically calibrating them, and identifying the environmental factors that may affect the captured reflectance data, which makes the use of these technologies not frequent [165]. Notably, Del Pozo et al. [166] reports using a Tetracam Mini-MCA6 for obtaining multispectral ortho-mosaics to map altered and unaltered materials and moisture of a historical church. Table 3 presents the characteristics of some miniaturized multispectral camera options, which have been implemented for terrestrial applications.

The reciprocity of visible-spectrum and infrared imaging is often considered essential for identifying damage on historic structures. Particularly, very near-infrared reflectance imaging is an effective tool for identifying biological colonization and the development of crusts on stone and concrete [167-172]. However, the cost and usability of hyperspectral/multispectral camera systems are often considered prohibitive factors for their implementation in the heritage sector, and thus the collection of multispectral data is performed via modified commercial cameras, and frequently with multi-sensor approaches. By removing the internal near-infrared cut-off filter, a charge-coupled device (CCD) or a complementary metal-oxide-semiconductor (CMOS)-based camera can be used as an affordable and agile alternative for multispectral acquisition. Narrow or wideband external filters allow capturing reflectance data at the very near-infrared range, while the 
camera retains user-friendly features and interfaces to a wide variety of photographic accessories and software [173-175]. Adamopoulos and Rinaudo [167], Lerma et al. [168], Meroño et al. [169], and Sánchez and Quirós [176] have used this method to obtain visible and very near-infrared images aiming to identify weathering on historical stone buildings or masonry. Thermographic reflectance imaging can be performed with an additional sensor (Figure 6).

Table 3. Multispectral cameras.

\begin{tabular}{cccc}
\hline Make and Model & Configuration & Spectral Bands & Resolution (Pixels) \\
\hline Buzzard Six Band & 6-camera & $\begin{array}{c}\text { B, G, R, NIR1, NIR2, } \\
\text { NIR3 }\end{array}$ & $1280 \times 1024$ \\
\hline MicaSense RedEdge & 5-camera & B, G, R, RE, NIR & $1280 \times 960$ \\
\hline Sal MAIA & 9-camera & $\begin{array}{c}\text { VIS, V, B, G, R, RE, } \\
\text { NIR1, NIR 2 }\end{array}$ & $1280 \times 960$ \\
\hline Tetracam ADC-Micro & single 3-band camera & G, R, NIR & $2048 \times 1536$ \\
\hline Tetracam $\mu$-MCA & 4, 6 or 12-camera & user-selectable & $1280 \times 1024$ \\
\hline
\end{tabular}
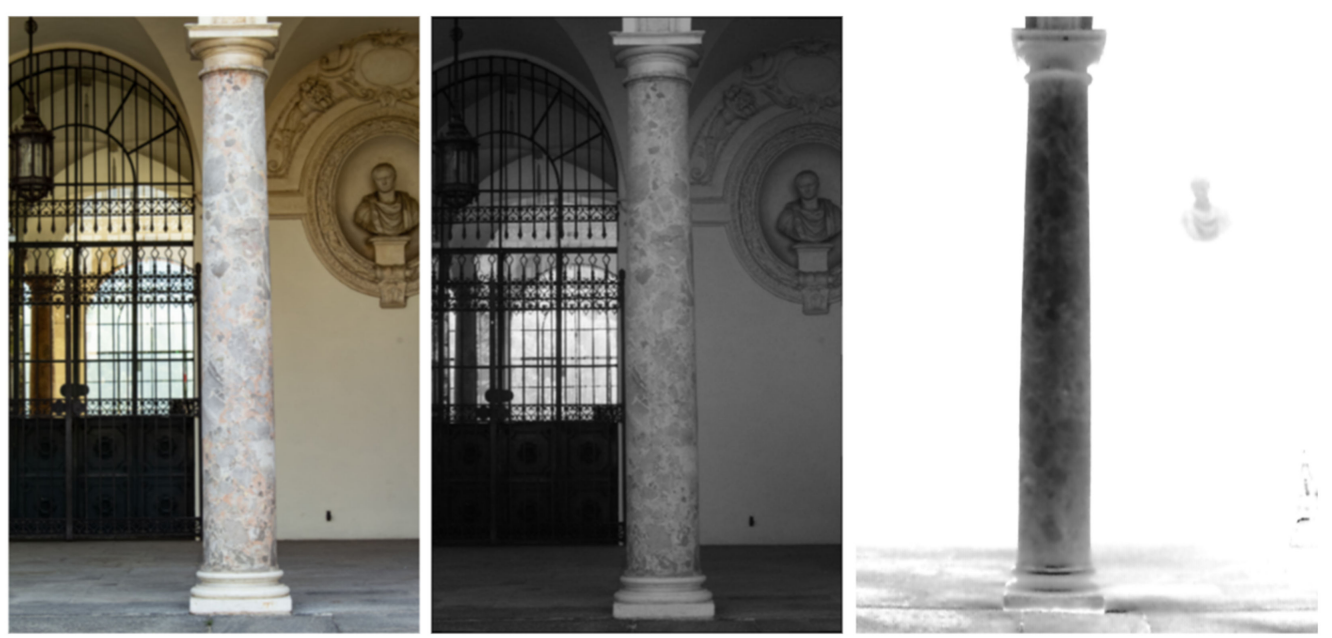

Figure 6. Spectral images captured at Turin's Castello del Valentino (Italy) main façade, right column: (left) color; (center) very near-infrared reflectance; (right) thermal.

\subsection{Ground-Penetrating Radar}

Ground-penetrating radar (GPR) is a geophysical prospection technique widely used for NDT applications. GPR is a noninvasive measurement method that utilizes high frequency (10-10,000 MHz) low-power electromagnetic pulse sequences to locate subsurface targets and interfaces between materials with different electrical and magnetic properties. The possibility of distinguishing between materials and mapping interfaces within visually opaque substances or earth material depends mainly on the propagation speed of electromagnetic waves and the difference in electrical conductivity and permeability between different materials $[177,178]$. GPR's operating principle is based on the generation of short-duration radio wave pulses by a transmitter, transmitted as wide beams at a speed that depends on the electromagnetic properties of the medium. The electromagnetic signal propagates in a medium (such as a structural element or subsoil). When it encounters an interface between materials with different electrical properties, then some of its energy is reflected or diffused back to the surface, some is refracted, and the residual energy of the pulse passes through the interface to deeper horizons, where this process can be repeated. The part of the wave reflected from an interface returns to the surface, where it is detected and recorded by the receiver [179]. The selection of the appropriate operating frequencies 
of the antenna depends on the purpose of the investigation and the requirements of the respective application of geo-radar inspection.

One primary challenge of GPR is the interpretation of the collected data, which highly depends on the quality of performed measurements, knowledge of the prospected medium dielectric properties, layering of the materials, and suitability of signal processing techniques $[180,181]$. An equally important issue for retrieving useful information from GPR measurements is the dimensionality of presenting the results, with $2 \mathrm{D}$ and $3 \mathrm{D}$ representations being the most frequent visualization scenarios for the historical structures' state of preservation assessment.

By performing a horizontal GPR scan along a linear profile, a 2D recording is obtained, which results from the successive individual one-dimensional traces retrieved along the path of the antenna. The retrieved data can be displayed as an image using a predefined color scale or palette (usually grayscale), matching the strength (range) of the recorded signal with a specific hue (brightness) of the selected palette (Figure 7). This image, also referred to as a $2 \mathrm{D}$ scan profile or radargram, represents a vertical section in the structure where the horizontal axis corresponds to the position of the antenna along with the scan, and the vertical axis to the time of the electromagnetic wave's dual-path, which corresponds to depth. Retrieving this type of result requires mechanical equipment with a built-in position encoder, which records the distance the antenna traverses along the scan line and the retrieval location of each individual trace [182].

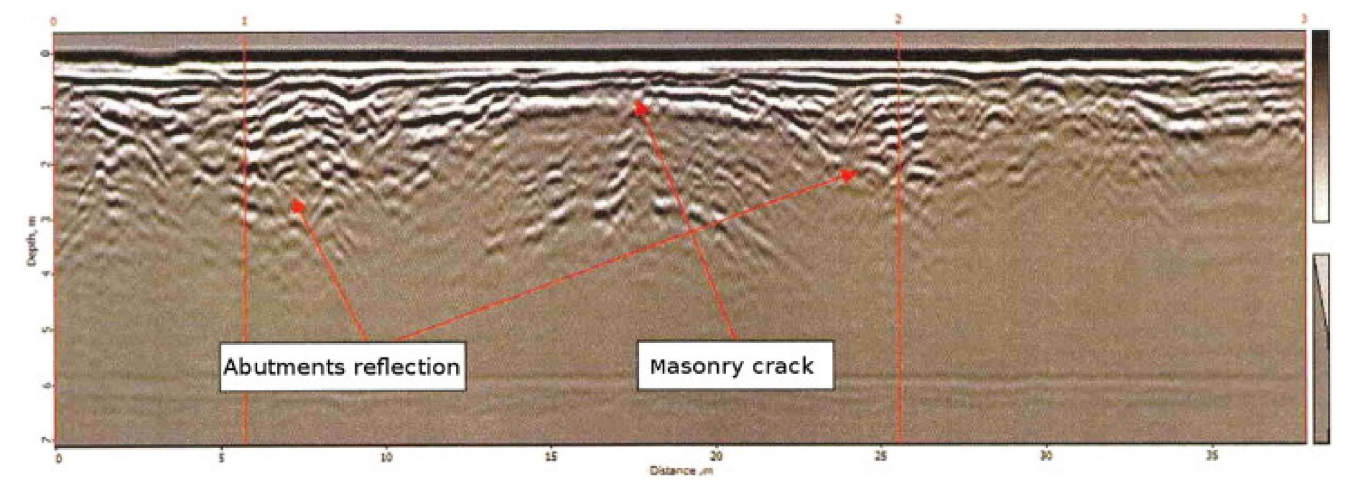

Figure 7. GPR profile above the deck of a historical masonry arch bridge [161].

Reflections from small or point scatterers below the ground, building element, or other medium's surface appear on the radargram as diffraction hyperbolas. This is because the electromagnetic waves are transmitted by the monostatic antenna in the form of a wide conical beam so that the receiver records the reflected signals from an undersurface target, not only when it passes just above the position where the target is located, but also in multiple scans before and after this position. The shape of the retrieved hyperbola depends on the antenna layout, the depth at which the point scatterer is located, the speed at which the electromagnetic waves propagate, and the scan spacing selected by the operator. At greater depths, the hyperbolae are larger because they consist of more scans. In addition, higher electromagnetic wave velocities (lower relative dielectric constant) produce wider hyperbolae and vice versa. Finally, the shorter the selected interval between scans (equivalent to a larger number of scans per unit of horizontal distance), the wider the hyperbolae recorded by point scatterers. The reflection always comes from the top of the point target, and the maximum (peak) of the recorded hyperbola curve corresponds precisely to the position where the target is. Usually, the larger the size (diameter) of a point scatterer, the stronger (wider) the hyperbolic reflection produced. The brightness or power of a hyperbolic reflection depends on the difference in electrical conductivity (and therefore relative dielectric constant) between the medium and the target. As a general rule, the brightness of a reflection produced by an interface between two materials with different dielectric properties is proportional to the dielectric contrast between the two materials, which means that the higher the contrast, the stronger is the reflection produced $[183,184]$. 
When scanning with GPR over a continuous boundary layer, the antenna receives consecutive reflections from the parts of said boundary, which in the retrieved 2D radargram appear in the form of a continuous reflecting layer that resembles the boundary layer. When the antenna crosses over an undersurface linear target of tubular shape transversely, i.e., perpendicular to the longitudinal axis of the target, then the recorded reflection will be hyperbolic, similar to the case of diffraction by point scatterers described above. If the antenna moves in parallel, i.e., along the target, then the reflection will appear as a continuous straight line, as long as the distance of the antenna from the subsurface target remains constant. Various subsurface inhomogeneities such as gaps (with air or water) produce strong reflections without a specific shape. Reflection polarity can also provide important information when interpreting GPR results. The presence of various subsurface discontinuities, such as large air-filled voids or cracks, is detected in the form of strong inverted phase reflections with a black-and-white sequence of colors and an indeterminate shape. In the case of disintegrated areas with high levels of moisture or water-filled voids, then the generated reflections will be strong but will show the normal polarity sequence (white-black-white), which is very important for the identification and differentiation between specific types of deterioration when interpreting radargrams. In addition, these reflections are usually stronger and more visible than those mentioned above. This phenomenon occurs because, for example, if we consider a stone or concrete structure, the dielectric contrast between the diffuser and water is much higher than the dielectric contrast between concrete and air [185,186].

By collecting multiple parallel 2D sections (time-slice method) or, in other words, by performing multiple horizontal scans on an $x-y$ axial plane of grid coordinates, a 3D data set can be recorded that can be used to construct subsurface models, thus improving the efficiency and quality of the signal interpretation [187]. Three-dimensional data retrieval requires the use of a properly designed measurement grid; the dimensions and distance between successive scan lines on each axis are user-defined. The way scans are performed on the grid is usually towards one direction starting from the same straight line ("normal" way of scanning), although there may be the possibility of zigzag measurements, in which the direction of the scans profiles changes alternately. Essentially, with this type of GPR scanning, the mapping of a subsurface area of interest is achieved, providing information about the location, depth, and orientation of the internal reflectors. Today, most of the processing software with which the geo-radar systems are equipped to provide the possibility of displaying the 3D data in various ways - such as in the form of horizontal sections at defined time ranges that correspond to depths parallel to the recording level, or isosurfaces-these are interpolated surfaces that represent subsurface points with a constant reflection coefficient or amplitude [188-191].

Since the (crucial for maintenance and damage repairing) inspection of historic buildings must, in many cases, be minimally invasive, making some common and valuable techniques' application not favorable, GPR has acquired great importance as a technique for revealing both historical and structural information [4,192-204]. Particularly, some issues of structural interest are the probable presence of fractures [205-207], voids [208], infiltrations of humidity [209,210], or metallic bars [211] due to previous restoration works, often not sufficiently documented. GPR evaluation is well advised, especially if new restoration interventions are planned [212,213]. Furthermore, nondestructive surveys by GPR can provide evidence for addressing the restorations appropriately and enable one to verify the success of the restoration works through post-intervention monitoring. Some topics of historical interest, which can be addressed through GPR surveys, are the presence of hidden rooms, floors, mosaics, and frescoes [214]. The changes that a structure has undergone through the centuries are often not adequately documented, or in other cases, the documents have been lost. Nevertheless, the significance of a retrieved buried target can be of both historical and structural value, as, for example, in the case of a hidden crypt under a church. 
Ground-penetrating radar is likewise an integral part of historical masonry arc bridge inspection. GPR acts as an effective nondestructive method for revealing essential historical, architectural, and structural characteristics, such as the presence of hidden arches, former shapes, moisture content, internal voids, and past restoration interventions [161,215-225]. However, their complex structural characteristics, including the heterogeneous filling and geometrical shape, often make the field acquisition, processing, and interpretation of data quite challenging.

\subsection{Active Elastic Wave Techniques}

Sensing methods focused on the propagation of elastic waves have been increasingly employed for the non-destructive inspection of historic structures and materials. The application of these techniques is based on the principle that wave propagation velocity (WPV) is associated with measurable parameters of the material through which it travels (density, elastic modulus, Poisson's ratio) [226]. The presence of damage (voids, cracks, defects) changes the material's physical properties, affecting propagation and, therefore, WPV measurements can be used for defect detection and quality control of materials [227]. The WPV is estimated by measuring the time that an elastic wave needs to transit from an emission point to another point located at the boundary surface of the material under examination. A receiver probe records the arrival of a pulse wave originating from the excitation source at the emission point. The precise and accurate measurement of the propagation time is a key factor when implementing active elastic wave techniques. Depending on the frequency content of the excitation pulse, WPV can be determined in the sonic or ultrasonic range [228]. Sonic and ultrasonic sensing techniques have many advantages compared with traditional invasive methods; however, there is a great number of parameters influencing the correct calculation of WPV. Roughness and defects of the historical surface under examination, and subsurface small cavities affect the results because the short wavelength of the pulse prevents it from passing even though very small voids between the surface and the receiver probe. Lack of knowledge about the distribution and heterogeneous physical properties of materials, especially for structures such as historic masonry, complicates the interpretation of results further, as well as water content $[180,229,230]$. Other limitations include operational costs due to high number of required measurements, calibration needs for different materials, and complexity of data elaboration caused by structural inhomogeneities [231,232].

Sonic and ultrasonic techniques applied for inspection purposes consider three types of acquisition methodologies conducted with different arrangement between excitation source and detector: (1) direct, in which the emission source (often a hammer) and the receiver are placed in line on opposite sides of the surveyed element; (2) semi-direct, in which the emission source and the receiver are placed with an angle between them; and (3) indirect, in which the emission source and the receiver are both located on the same face of the element in a vertical or horizontal line [233]. Commonly, surveys of building and infrastructure elements are carried out with a 2D array, for example, along longitudinal or transverse sections of columns and walls. Sometimes many 2D tomographic profiles are arranged to construct a 3D model. The full 3D sonic or ultrasonic tomographies are especially devoted to the internal study of pillars and columns [234]. Many examples of built heritage inspection through sonic and ultrasonic sensing can be found in recent bibliography $[207,229,235-243]$.

\section{Data Fusion}

As a general multidisciplinary approach, the term data fusion implies integration of data from different sources to enhance their potential value, interpretability, and allow the generation of high-quality visual representations. Sensor fusion, data integration, and information fusion are similar terms often referring to the same concept. However, in the framework of this review, as sensor fusion approaches are referred to only those employing 
simultaneous data acquisition with multi-sensor configurations, to distinguish them from data fusion approaches performed at a post-acquisition processing stage.

Multisource data fusion techniques are beneficial for built heritage condition monitoring. They significantly improve holistic documentation, enhance the properties of recorded data, enable integrated analysis, support long-term inspection, and minimize misinterpretations caused by cross-examining the multi-disciplinary information. Data fusion approaches are most often categorized depending on the stage of data processing at which fusion occurs [244]. Ramos and Remondino [245] proposed an expanded classification of data fusion procedures regarding different aspects. As concerns cultural heritage applications, generally there are not incremental approaches for fusing heterogeneous data for inspection and monitoring. However, the registration of metric data and other metric or qualitative information requires a common reference system with known parameters, where their spatial integration can take place. Additionally, the integration of data from different sources at the pixel level requires images (or orthoimage-mosaics) that represent the same plane and are of the scene sampling distance.

The task of integrating multi-sensor data depends on aspects such as the spatial and radiometric resolution, positional accuracy, and dimensionality of the fusion [246]. Integrative 3D modeling approaches, especially those involving TLS and IBM, are a widely discussed topic of data fusion, and follow different pipelines [247]. However, the fusion between (geo)metric data and non-metric data is less often debated. Besides, close-range sensing data purposed for nondestructive monitoring are seldom recorded in a non-metric manner. Their inherent heterogeneity, a result of sensing at multiple wavelengths with vastly different instrumentation, hinders the integration processes.

Often, the near-infrared spectral images' similarities with color images allow for the high-resolution texturing of historical structures' 3D representations or the direct implementation of IBM-driven processing, thus facilitating integration with other metric data sources. The problematics of integrating thermograms with metric data come from the vast dissimilarities comparing with visible-spectrum images and concern both their spatial (low resolution) and radiometric (different observable features) characteristics. Methodologies on the fusion of thermographic and geometric data depend on sensor registration (optical camera with thermal camera/laser scanner with thermal camera), product registration (thermogram with point cloud/thermogram with 3D model), or hybrid photogrammetric techniques. Implementing one of the above data fusion techniques largely depends on the scale of the survey and the available equipment and produces thermaltextured 3D point clouds or models. Furthermore, data collected with subsurface inspection methods using radar, ultrasonic and sonic techniques can also be integrated, when the position of utilized antennae is estimated or tracked, thus allowing the referencing into a given coordinate system; however, this type of fusion refers mainly to information visualization and not integrated analysis.

\subsection{Integration between Photogrammetric and Ranging Techniques}

The primary goal of heritage geometric recording is the generation of complete, accurate, and photorealistic 3D representations and 2D metric derivatives, such as orthoimagemosaics and vector drawings. As discussed in Sections 2.2 and 2.3, there is a wide range of advanced active and passive sensors and sensing techniques for geometric recording, producing different data. Integrative IBM and TLS approaches are the standard approach for modeling ancient and historical structures and ensure that density, accuracy, and texture-resolution predefined specifications are met [56,248-250]. Fusion approaches introduced for multisource point cloud (3D-to-3D) registration (and successively coloring) are: manual annotation of common features [251], iterative closest point (ICP) [252,253], feature-based [254], and georeferencing-based [35]. The rapid increase in the implementation of unmanned aerial systems (UAS) for cultural heritage IBM has recently introduced fascinating integrative approaches, on the convergence of TLS and low-altitude aerial photogrammetry [255-259] (see Section 4.1). 


\subsection{Multispectral Data}

Regarding multi-sensor recording approaches, and some designs of integrated devices, it is anticipated that the images from different spectral channels require to be shifted or spatially re-scaled to be registered (2D-to-2D fusion) to form aligned multispectral image cubes. There are several algorithms associated with image registration [260]. Image registration involving linear shifts is relatively easy to compute and can be applied by performing cross-correlation. Spatial image scaling that involved re-sampling could result in some loss of information; as a result, it is best to design the system's optics to avoid scaling of the images. High-resolution imaging of large objects inevitably involves mosaicking of the images. Adjacent images need to be taken with sufficient overlap to allow automatic image registration. When the shifts are linear, a simple cross-correlation algorithm can be used for image registration. Regarding cultural heritage applications, registering images collected in different spectra has often been addressed through the manual identification of common features [261].

One prevalent form of multispectral data fusion for built heritage monitoring involves multi-sensor acquisition. IBM and TLS-produced ortho-mosaics referenced at the same coordinate system can be treated as multispectral images. Sánchez-Aparicio et al. [262], Del Pozo et al. [263], and Conde et al. [264] experimented with fusing data from laser scanners operating at different wavelengths, multispectral and commercial digital cameras to produce multispectral ortho-mosaics for detecting pathologies in constructions.

\subsection{Thermographic Data}

Registration between orthorectified thermal-infrared and color images/image-mosaics is usually performed for cultural heritage applications by manually identifying common points distinguishable in both spectra (characteristic points, or, more commonly, special targets with different reflectance characteristics) to define the necessary transformation $[265,266]$. However, the most frequently applied approach for the fusion of thermal and metric data of historic architectures has been integrating thermograms and 3D measurements, collected with individual proximal sensing techniques. This process frequently implies registering dense point clouds (or derivative 3D models) captured by TLS - containing metric spatial information-and thermographic images. This approach is considered the most costeffective, especially when complete thermographic mapping of a historic structure or structural element is required. The estimation of the geometric relation between a point cloud/3D model and a thermogram (the relative position and the orientation matrix) is realized by defining common features, allowing the projection of the thermal intensities to create a thermal texture.

Due to the limitations imposed by the low spatial resolution of thermal infrared images [267], research on thermographic modeling for built cultural heritage has largely concentrated on pipelines for reconstructing the 3D shape from color image datasets, and applying the texture from registered thermal infrared image datasets and hybrid workflows, which apply the photogrammetric principles on both color and thermal infrared image datasets, but use only the latter for texturing [268]. González-Aguilera et al. [269], Dlesk et al. [270], and Patrucco et al. [271] performed image-based modeling using thermal infrared images captured with NEC TH9260, FLIR E95, and FLIR SC660 thermal cameras, respectively, to reconstruct digitally and to inspect built heritage. Recent approaches take advantage of the thermal and color image sensors integrated into the thermographic camera [272-275].

The first approaches for thermal texturing via 2D-to-3D registration were developed on a manual basis. This method has been implemented by Spanò et al. [276], Zalama et al. [277], Costanzo et al. [278], and Mileto et al. [279] to investigate the pathology of historical buildings. However, since the correspondences between thermal images and 3D metric products may not always be visible, approaches have been recently developed to perform this $2 \mathrm{D}$-to-3D registration automatically using features extracted from point clouds and thermal images $[280,281]$. 
Methodologies for simultaneous recording of high-density geometric and thermographic data have also been established, facilitating massive and more agile thermographic 3D modeling. Custom-made multi-sensor equipment has often been employed with this aim, necessitating the registration between different sensors used during acquisition. The sensor registration parameters consist of a vector of the differences in the sensors' relative position and the rotation angles between them, and they are necessary to transform and integrate data into the same coordinate system [282-288]. Overall, sensor registration that includes thermographic cameras is not usual due to thermal measurements' requirements, as regards to angle and distance of acquisition [289].

The combined application of IRT and GPR can be helpful for the detection and characterization of moisture $[290,291]$, but the produced results (thermograms and 2D slices) are not integrated, because they represent different planes of the investigated structures. Although some research has been produced towards the pixel-level fusion of IRT and GPR for concrete bridge inspection [292], the application for built heritage poses many challenges due to the heterogeneity of historic materials, and their constant degradation.

\subsection{Radar, Ultrasonic, and Sonic Data}

Unlike thermography, GPR data are more challenging to interpret and have lower spatial resolution than TLS and close-range photogrammetry and, thus, are usually acquired and used independently $[293,294]$. The expected level of fusion between geometric and geophysical data for architectural heritage nondestructive investigations is frequently the registration of GPR slices or surfaces interpolated from 3D grid-organized GPR measurements, and metric products computed with methods for reality capturing [295,296]. When historical structures' surfaces with relatively flat geometries are investigated, the integration in 3D space is, according to the bibliography, achieved through measuring the 3D positioning of control points (usually the start and end-point) of the scan lines [297-300]. Apart from registration, the availability of a dense geometric 3D model or point cloud can also assist the spatial correction of GRP data collected for structures with more complex geometries, the most common example being historic bridges [301-309]. Penetrating radar exploration of historic structure's columns may require only a simplified knowledge of the geometrical shapes $[310,311]$. The integration of positioning systems, laser scanning, and GPR presents exciting potential for integrated surface and subsurface mapping but is subject to limitations stemming from the multi-sensor approach [312].

Ultrasonic and sonic sensing, likewise, have lower spatial resolution than TLS and close-range photogrammetry. However, the registration of ultrasonic/sonic measurements with color-textured 3D models and backscattered laser intensity-textured 3D models, from photogrammetry and TLS, respectively, can benefit the interpretation of shallow and inner anomalies of columns and pillars [313,314]. At the same time, referencing of longitudinal wave velocity maps or tomographic slices helps the better understanding of a historical asset's structural condition in three dimensions, especially when integrated with deformation maps [236,237].

\section{Conclusions and Outlooks}

In order to facilitate cohesive monitoring of built heritage, an identification of the advantages and limitations of each close-range sensing evaluation technique and their integrated use is necessary. Table 4 presents a brief comparison of close-range sensing techniques for build heritage inspection and monitoring based on reviewed recent literature.

Laser Scanning and IBM satisfy the 3D modeling needs for inspection, multitemporal deformation monitoring, numerical modeling, and building information modeling (BIM) $[315,316]$, and enable surface feature extraction regarding deterioration and physical defects. The integration between them emphasizes the complementarity of geometric and color information. These techniques employ mobile instrumentation, are easily adapted for complicated acquisition scenarios, and can reach millimetric accuracy for the extracted features; however, they cannot provide any subsurface information. Conditionally, TLS 
can be applied for surface moisture detection, subject to calibration and knowledge of the material's emissivity at the laser instrument's operating band.

Table 4. Characteristics of close-range sensing techniques for built heritage applications.

\begin{tabular}{|c|c|c|c|c|c|c|}
\hline & Deformations & $\begin{array}{l}\text { Surface } \\
\text { Features }\end{array}$ & $\begin{array}{c}\text { Subsurface } \\
\text { Features }\end{array}$ & $\begin{array}{l}\text { Material } \\
\text { Depth }\end{array}$ & $\begin{array}{c}\text { Thermal } \\
\text { Properties }\end{array}$ & $\begin{array}{l}\text { Moisture } \\
\text { Detection }\end{array}$ \\
\hline Close Range Photogrammetry & $x$ & $x$ & & & & \\
\hline Laser Scanning & $\times$ & $\times$ & & & & $\times$ \\
\hline Infrared Thermography & & $\times$ & & & $\times$ & $x$ \\
\hline Near-Infrared/Multispectral Imaging & & $\times$ & & & & $x$ \\
\hline Ground Penetrating Radar & & & $\times$ & $\times$ & & $\times$ \\
\hline Ultrasound/Sonic & & & $x$ & $x$ & & $x$ \\
\hline
\end{tabular}

IRT evaluation is appropriate for surface detection and feature extraction of defects and moisture, but is less mobile than IBM/TLS and requires knowledge of the ambient and material influence on LWIR radiance measurements. The integration with metric surveying allows for the quantification of extracted features and their correlation in 3D space to address potential sources of moisture, subsurface radiant sources, and calculate building envelopes for sustainable conservation. In addition, the resolution of thermographic results can be significantly improved through pan sharpening, super-resolution enhancement, or hybrid color-thermal IBM.

Near-infrared and multispectral imaging offer solutions for surface pattern extraction concerning weathering, moisture, and biological colonization, providing higher thematic accuracy of the extracted features comparing with color imaging and IBM. Especially the combination with learning-based digital image segmentation results in rapid mapping of the surface condition. However, challenges occur from the implementation of multi-sensor instrumentation due to increased cost, reduced mobility, and calibration needs.

GPR introduces one of the most promising monitoring technologies due to its ability to identify material depth and locate discontinuities between materials due to their different dielectric properties. The fusion of GPR measurements with geometric data enables spatial correction for structures of complex geometry but simultaneously facilitates better 3D visualization of the prospection results and increases the accuracy of locating material discontinuities defects in 3D. Furthermore, 3D modeling, GPR and ultrasonic/sonic techniques integration support truthful numerical modeling and parametrization for structural health analysis.

In the sense of pixel-level fusion, data integration for built heritage is scarcely being applied through the quantization of multitemporal or multispectral images to increase interpretation, utilizing clustering classification or principal component analysis. On the other hand, integrated management of nondestructively recorded data through a geographic information system (GIS) is a more common approach that allows geo-processing analysis for thematic pathology representation. The concept of integrating nondestructive evaluation and BIM is a novel concept that aims to facilitate management, support the restoration and rehabilitation process, enhance historical research, and promote building sustainability in an integrated way [317-320].

\subsection{The Aerial Perspective}

The recent substantial progress of uncrewed platform manufacturing, the increasing miniaturization of sensing payloads, and decreasing cost of integrated microelectronics, have gradually fostered the adoption of UAS for low-altitude aerial inspection of historic structures $[111,259,295]$. State-of-the-art UAS-born sensors include orientation systems, color cameras, multispectral cameras, hyperspectral cameras, infrared thermography cameras, action cameras, and LiDAR instruments [321]. Non-destructive recording that utilizes 
UAS platforms is considerably more cost-effective for covering large historic building complexes (and their surroundings) and inaccessible areas of historical significance than traditional data acquisition methods [322].

UAS-based close-range photogrammetry is a proven stand-alone approach to 3D modeling of built heritage [323-329]. Nevertheless, it can also support ground means such as terrestrial LiDAR [330-333] and simultaneous localization and mapping (SLAM)-based recording techniques $[334,335]$. UAS-born LiDAR is a 3D recording approach less explored for historical structures [336] than for landscape features induced by buried archaeological remains. Planning of the aerial surveys [258,337] is not the only important parameter for structural inspection, as the optimization of recorded large-volume data [338,339] can be considered equally essential. Furthermore, the automatic segmentation and classification of derived point clouds and 3D models [340-342] has particular importance for the semantic description and virtual reassembly of historic structures, especially for BIM integration [343], and web and augmented/mixed reality applications [344]. UAS-based photogrammetry has also been implemented for assessing damage in post-disaster scenarios through multitemporal 3D modeling [345-347], while the classification of images and point clouds collected with UAS sensors can also support structural health monitoring $[348,349]$. To conclude, the use of UAS presents us with an exciting prospect for damaged built heritage monitoring by supporting terrestrial non-destructive surveys via high-resolution modeling, multispectral mapping [162], and providing the necessary input for rapid inspections and numerical modeling [350].

Author Contributions: Conceptualization, E.A.; formal analysis, E.A.; investigation, E.A.; writingoriginal draft preparation, E.A.; writing - review and editing, E.A. and F.R.; supervision, F.R.; funding acquisition, E.A. All authors have read and agreed to the published version of the manuscript.

Funding: This paper is part of the research conducted for the 'Technology Driven Sciences: Technologies for Cultural Heritage'-T4C doctoral program at the University of Turin. The presented research received funding from the European Union's Framework Program for Research and Innovation Horizon 2020 (H2020) under the Marie Skłodowska-Curie Actions COFUND scheme (grant agreement number 754511) and by the foundation Compagnia di San Paolo.

Conflicts of Interest: The authors declare no conflict of interest.

\section{References}

1. Kioussi, A.; Karoglou, M.; Labropoulos, K.; Bakolas, A.; Moropoulou, A. Integrated documentation protocols enabling decision making in cultural heritage protection. J. Cult. Herit. 2013, 14, e141-e146. [CrossRef]

2. Alexakis, E.; Delegou, E.T.; Lampropoulos, K.C.; Apostolopoulou, M.; Ntoutsi, I.; Moropoulou, A. NDT as a monitoring tool of the works progress and the assessment of materials and rehabilitation interventions at the holy aedicule of the holy sepulchre. Constr. Build. Mater. 2018, 189, 512-526. [CrossRef]

3. Kilic, G. Using advanced NDT for historic buildings: Towards an integrated multidisciplinary health assessment strategy. J. Cult. Herit. 2015, 16, 526-535. [CrossRef]

4. Pérez-Gracia, V.; Caselles, J.O.; Clapés, J.; Martinez, G.; Osorio, R. Non-destructive analysis in cultural heritage buildings: Evaluating the Mallorca cathedral supporting structures. NDT E Int. 2013, 59, 40-47. [CrossRef]

5. Moropoulou, A.; Labropoulos, K.C. Non-Destructive Testing for Assessing Structural Damage and Interventions Effectiveness for Built Cultural Heritage Protection. In Handbook of Research on Seismic Assessment and Rehabilitation of Historic Structures; Advances in Civil and Industrial Engineering; Asteris, P.G., Plevris, V., Eds.; IGI Global: Hershey, PA, USA, 2015; pp. 448-499, ISBN 978-1-4666-8286-3.

6. De Vita, M.; Massara, G.; De Berardinis, P. More comprehension, more protection: Non-destructive techniques in the survey of the former S. Salvatore hospital in L'Aquila, Italy. SCIRES-IT 2019, 9, 85-94. [CrossRef]

7. Bosiljkov, V.; Uranjek, M.; Žarnić, R.; Bokan-Bosiljkov, V. An integrated diagnostic approach for the assessment of historic masonry structures. J. Cult. Herit. 2010, 11, 239-249. [CrossRef]

8. Cardinali, V.; Castellini, M.; Cristofaro, M.T.; Lacanna, G.; Coli, M.; De Stefano, M.; Tanganelli, M. Integrated techniques for the structural assessment of cultural heritage masonry buildings: Application to Palazzo Cocchi-Serristori in Florence. J. Cult. Herit. Manag. Sustain. Dev. 2021. ahead-of-print. [CrossRef]

9. Diz-Mellado, E.; Mascort-Albea, E.J.; Romero-Hernández, R.; Galán-Marín, C.; Rivera-Gómez, C.; Ruiz-Jaramillo, J.; JaramilloMorilla, A. Non-destructive testing and finite element method integrated procedure for heritage diagnosis: The Seville Cathedral case study. J. Build. Eng. 2021, 37, 102134. [CrossRef] 
10. Guadagnuolo, M.; Faella, G.; Donadio, A.; Ferri, L. Integrated evaluation of the Church of S. Nicola Di Mira: Conservation versus safety. NDT E Int. 2014, 68, 53-65. [CrossRef]

11. Napolitano, R.; Hess, M.; Glisic, B. Integrating non-destructive testing, laser scanning, and numerical modeling for damage assessment: The room of the elements. Heritage 2019, 2, 151-168. [CrossRef]

12. Conde, B.; Ramos, L.F.; Oliveira, D.V.; Riveiro, B.; Solla, M. Structural Assessment of Masonry Arch Bridges by Combination of Non-Destructive Testing Techniques and Three-Dimensional Numerical Modelling: Application to Vilanova Bridge. Eng. Struct. 2017, 148, 621-638. [CrossRef]

13. Adamopoulos, E.; Tsilimantou, E.; Keramidas, V.; Apostolopoulou, M.; Karoglou, M.; Tapinaki, S.; Ioannidis, C.; Georgopoulos, A.; Moropoulou, A. Multi-sensor documentation of metric and qualitative information of historic stone structures. ISPRS Ann. Photogramm. Remote Sens. Spatial Inf. Sci. 2017, 4, 1-8. [CrossRef]

14. Giuffrida, D.; Mollica Nardo, V.; Neri, D.; Cucinotta, G.; Calabrò, I.V.; Pace, L.; Ponterio, R.C. A multi-analytical study for the enhancement and accessibility of archaeological heritage: The Churches of San Nicola and San Basilio in Motta Sant'Agata (RC, Italy). Remote Sens. 2021, 13, 3738. [CrossRef]

15. Francisco, C.; Gonçalves, L.; Gaspar, F.; Rodrigues, H.; Carracelas, M.S.; Luna, I.P.; Gonçalves, G.; Providência, P. Data Acquisition in Cultural Heritage Buildings Using Non-destructive Techniques, and Its Gathering with BIM-The Case Study of the Gothic Monastery of Batalha in Portugal. In Sustainability and Automation in Smart Constructions; Advances in Science, Technology \& Innovation; Rodrigues, H., Gaspar, F., Fernandes, P., Mateus, A., Eds.; Springer International Publishing: Cham, Switzerland, 2021; pp. 59-68, ISBN 978-3-030-35532-6.

16. Pavlidis, G.; Koutsoudis, A.; Arnaoutoglou, F.; Tsioukas, V.; Chamzas, C. Methods for 3D digitization of cultural heritage. J. Cult. Herit. 2007, 8, 93-98. [CrossRef]

17. De Luca, L. Methods, formalisms and tools for the semantic-based surveying and representation of architectural heritage. Appl. Geomat. 2011, 6, 115-139. [CrossRef]

18. Remondino, F. Heritage recording and 3D modeling with photogrammetry and 3D scanning. Remote Sens. 2011, 3, 1104-1138. [CrossRef]

19. Georgopoulos, A.; Stathopoulou, E.K. Data acquisition for 3D geometric recording: State of the art and recent innovations. In Heritage and Archaeology in the Digital Age; Vincent, M.L., López-Menchero Bendicho, V.M., Ioannides, M., Levy, T.E., Eds.; Springer International Publishing: Cham, Switzerland, 2017; pp. 1-26, ISBN 978-3-319-65369-3.

20. Masciotta, M.G.; Morais, M.J.; Ramos, L.F.; Oliveira, D.V.; Sánchez-Aparicio, L.J.; González-Aguilera, D. A digital-based integrated methodology for the preventive conservation of cultural heritage: The experience of HeritageCare Project. Int. J. Archit. Herit. 2019, 15, 844-863. [CrossRef]

21. Napolitano, R.; Liu, Z.; Sun, C.; Glisic, B. Combination of image-based documentation and augmented reality for structural health monitoring and building pathology. Front. Built Environ. 2019, 5, 50. [CrossRef]

22. Achille, C.; Tommasi, C.; Rechichi, F.; Fassi, F.; De Filippis, E. Towards an advanced conservation strategy: A structured database for sharing 3D documentation between expert users. Int. Arch. Photogramm. Remote Sens. Spatial Inf. Sci. 2019, 42, 9-16. [CrossRef]

23. Fassi, F.; Achille, C.; Mandelli, A.; Rechichi, F.; Parri, S. A new idea of BIM system for vizualization, web sharing and using huge complex 3D models for facility management. Int. Arch. Photogramm. Remote Sens. Spatial Inf. Sci. 2015, 40, 359-366. [CrossRef]

24. Maietti, F.; Medici, M.; Ferrari, F. From semantic-aware digital models to augmented reality applications for architectural heritage conservation and restoration. Disegnarecon 2021, 14, 17. [CrossRef]

25. Marques, L.; Roca, J.; Tenedório, J.A. Valorisation of urban elements through 3D models generated from image matching point clouds and augmented reality visualization based in mobile platforms. In Proceedings of the Remote Sensing Technologies and Applications in Urban Environments, Warsaw, Poland, 11-14 September 2017; Heldens, W., Chrysoulakis, N., Erbertseder, T., Zhang, Y., Eds.; SPIE: Bellingham, WA, USA, 2017; Volume 10431.

26. Marques, L.; Tenedório, J.A.; Burns, M.; Româo, T.; Birra, F.; Marques, J.; Pires, A. Cultural heritage 3D modelling and visualisation within an augmented reality environment, based on geographic information technologies and mobile platforms. Archit. City Environ. 2017, 11, 117-136. [CrossRef]

27. Messaoudi, T.; Véron, P.; Halin, G.; De Luca, L. An ontological model for the reality-based 3D annotation of heritage building conservation state. J. Cult. Herit. 2018, 29, 100-112. [CrossRef]

28. Rechichi, F.; Mandelli, A.; Achille, C.; Fassi, F. Sharing high-resolution models and information on web: The web module of BIM3DSG system. Int. Arch. Photogramm. Remote Sens. Spatial Inf. Sci. 2016, 41, 703-710. [CrossRef]

29. Stefani, C.; Brunetaud, X.; Janvier-Badosa, S.; Beck, K.; De Luca, L.; Al-Mukhtar, M. Developing a toolkit for mapping and displaying stone alteration on a web-based documentation platform. J. Cult. Herit. 2014, 15, 1-9. [CrossRef]

30. Alshawabkeh, Y.; El-Khalili, M.; Almasri, E.; Bala'awi, F.; Al-Massarweh, A. Heritage documentation using laser scanner and photogrammetry. The case study of Qasr Al-Abidit, Jordan. Digit. Appl. Archaeol. Cult. Herit. 2020, 16, e00133. [CrossRef]

31. Gines, J.L.C.; Cervera, C.B. Toward hybrid modeling and automatic planimetry for graphic documentation of the archaeological heritage: The Cortina family pantheon in the cemetery of Valencia. Int. J. Archit. Herit. 2020, 14, 1210-1220. [CrossRef]

32. Guarnieri, A.; Milan, N.; Vettore, A. Monitoring of complex structure for structural control using terrestrial laser scanning (Tls) and photogrammetry. Int. J. Archit. Herit. 2013, 7, 54-67. [CrossRef]

33. Grussenmeyer, P.; Alby, E.; Assali, P.; Poitevin, V.; Hullo, J.-F.; Smigiel, E. Accurate Documentation in Cultural Heritage by Merging TLS and High-Resolution Photogrammetric Data. In Proc. SPIE 8085, Videometrics, Range Imaging, and Applications XI, 
Proceedings of SPIE Optical Metrology, 2011, Munich, Germany, 25-26 May 2011; Remondino, F., Shortis, M.R., Eds.; SPIE: Munich, Germany, 21 June 2011; p. 808508.

34. Mateus, L.; Fernández, J.; Ferreira, V.; Oliveira, C.; Aguiar, J.; Gago, A.S.; Pacheco, P.; Pernão, J. Terrestrial laser scanning and digital photogrammetry for heritage conservation: Case study of the Historical Walls of Lagos, Portugal. Int. Arch. Photogramm. Remote Sens. Spatial Inf. Sci. 2019, 42, 843-847. [CrossRef]

35. Murtiyoso, A.; Grussenmeyer, P.; Suwardhi, D.; Awalludin, R. Multi-scale and multi-sensor 3D documentation of heritage complexes in urban areas. ISPRS Int. J. Geoinf. 2018, 7, 483. [CrossRef]

36. Remondino, F.; Rizzi, A. Reality-based 3D documentation of natural and cultural heritage sites-Techniques, problems, and examples. Appl. Geomat. 2010, 2, 85-100. [CrossRef]

37. Budak, I.; Stojakovic, V.; Korolija Crkvenjakov, D.; Obradovic, R.; Molisevic, M.; Sokac, M. Development of expert system for the selection of 3D digitization method in tangible cultural heritage. Teh. Vjesn. 2019, 26, 838-844. [CrossRef]

38. Barsanti, S.G.; Remondino, F.; Fenández-Palacios, B.J.; Visintini, D. Critical factors and guidelines for 3D surveying and modelling in cultural heritage. Int. J. Herit. Digit. Era 2014, 3, 141-158. [CrossRef]

39. Hassani, F. Documentation of cultural heritage; techniques, potentials, and constraints. Int. Arch. Photogramm. Remote Sens. Spatial Inf. Sci. 2015, 40, 207-214. [CrossRef]

40. Haddad, N.A. From ground surveying to 3D laser scanner: A review of techniques used for spatial documentation of historic sites. J. King Saud. Univ. Eng. Sci. 2011, 23, 109-118. [CrossRef]

41. Wang, B.; Zhong, S.; Lee, T.-L.; Fancey, K.S.; Mi, J. Non-destructive testing and evaluation of composite materials/structures: A state-of-the-art review. Adv. Mech. Eng. 2020, 12, 1-28. [CrossRef]

42. El Masri, Y.; Rakha, T. A Scoping review of nondestructive testing (NDT) techniques in building performance diagnostic inspections. Constr. Built. Mater. 2020, 265, 120542. [CrossRef]

43. Grussenmeyer, P.; Landes, T.; Doneus, M.; Lerma, J.L. Basics of range-based modelling techniques in cultural heritage 3D recording. In 3D Recording, Documentation and Management of Cultural Heritage; Stylianidis, E., Remondino, F., Eds.; Whittles Publishing: Dunbeath, UK, 2016; pp. 305-368, ISBN 978-1-84995-168-5.

44. Lerma, J.L. (Ed.) Theory and Practice on Terrestrial Laser Scanning: Training Material Based on Practical Applications; Universidad Politecnica de Valencia Editorial: Valencia, Spain, 2008; ISBN 978-8-48363-312-0.

45. Beraldin, J.-A.; Blais, F.; Lohr, U. Laser scanning technology. In Airborne and Terrestrial Laser Scanning; Vosselman, G., Maas, H.-G., Eds.; Whittles Publishing: Dunbeath, UK, 2010; pp. 1-42, ISBN 978-1-904445-87-6.

46. Petrie, G.; Toth, C.K. Terrestrial laser scanners. In Topographic Laser Ranging and Scanning: Principles and Processing, 2nd ed.; Shan, J., Toth, C.K., Eds.; CRC Press: Boca Raton, FL, USA, 2018; pp. 87-128, ISBN 978-1-4987-7227-3.

47. Vacca, G.; Deidda, M.; Dessi, A.; Marras, M. Laser scanner survey to cultural heritage conservation and restoration. Int. Arch. Photogramm. Remote Sens. Spatial Inf. Sci. 2012, 39, 589-594. [CrossRef]

48. Ahn, J.; Wohn, K. Interactive scan planning for heritage recording. Multimed. Tools Appl. 2016, 75, 3655-3675. [CrossRef]

49. Metawie, M.; Marzouk, M. Optimizing laser scanning positions in buildings exteriors: Heritage building applications. J. Civ. Eng. Manag. 2020, 26, 304-314. [CrossRef]

50. Barber, D.; Mills, J.; Bryan, P. Towards a standard specification for terrestrial laser scanning of cultural heritage. Int. Arch. Photogramm. Remote Sens. Spatial Inf. Sci. 2003, 34, 619-624.

51. Bouaziz, S.; Tagliasacchi, A.; Pauly, M. Sparse iterative closest point. Comput. Graph. Forum 2013, 32, 113-123. [CrossRef]

52. Fabado, S.; Seguí, A.E.; Cabrelles, M.; Navarro, S.; García-De-San-Miguel, D.; Lerma, J.L. 3DVEM software modules for efficient management of point clouds and photorealistic 3D models. Int. Arch. Photogramm. Remote Sens. Spatial Inf. Sci. 2013, 40, 255-260. [CrossRef]

53. Lachat, E.; Landes, T.; Grussenmeyer, P. Comparison of point cloud registration algorithms for better result assessment-Towards an open-source solution. Int. Arch. Photogramm. Remote Sens. Spatial Inf. Sci. 2018, 42, 551-558. [CrossRef]

54. Cheng, L.; Chen, S.; Liu, X.; Xu, H.; Wu, Y.; Li, M.; Chen, Y. Registration of laser scanning point clouds: A review. Sensors 2018, 18, 1641. [CrossRef] [PubMed]

55. Dong, Z.; Liang, F.; Yang, B.; Xu, Y.; Zang, Y.; Li, J.; Wang, Y.; Dai, W.; Fan, H.; Hyyppä, J.; et al. Registration of large-scale terrestrial laser scanner point clouds: A review and benchmark. ISPRS J. Photogramm. 2020, 163, 327-342. [CrossRef]

56. Fassi, F.; Achille, C.; Fregonese, L. Surveying and modelling the main spire of Milan Cathedral using multiple data sources. Photogramm. Rec. 2011, 26, 462-487. [CrossRef]

57. Dorninger, P.; Nothegger, C.; Rasztovits, S. Efficient 3D documentation of neptune fountain in the park of Schönbrunn palace at millimeter scale. ISPRS Ann. Photogramm. Remote Sens. Spatial Inf. Sci. 2013, 2, 103-108. [CrossRef]

58. Pritchard, D.; Sperner, J.; Hoepner, S.; Tenschert, R. Terrestrial laser scanning for heritage conservation:The cologne cathedral documentation project. ISPRS Ann. Photogramm. Remote Sens. Spatial Inf. Sci. 2017, 4, 213-220. [CrossRef]

59. Wilson, L.; Rawlinson, A.; Frost, A.; Hepher, J. 3D Digital Documentation for Disaster Management in Historic Buildings: Applications Following Fire Damage at the Mackintosh Building, The Glasgow School of Art. J. Cult. Herit. 2018, 31, 24-32. [CrossRef]

60. Kincey, M.; Gerrard, C.; Warburton, J. Quantifying erosion of 'at risk' archaeological sites using repeat terrestrial laser scanning. J. Archaeol. Sci. Rep. 2017, 12, 405-424. [CrossRef] 
61. Guarnieri, A.; Fissore, F.; Masiero, A.; Vettore, A. From TLS survey to 3D solid modeling for documentation of built heritage: The case study of Porta Savonarola in Padua. Int. Arch. Photogramm. Remote Sens. Spatial Inf. Sci. 2017, 42, 303-308. [CrossRef]

62. Monego, M.; Fabris, M.; Menin, A.; Achilli, V. 3-D survey applied to industrial archaeology by TLS methodology. Int. Arch. Photogramm. Remote Sens. Spatial Inf. Sci. 2017, 42, 449-455. [CrossRef]

63. Monego, M.; Menin, A.; Fabris, M.; Achilli, V. 3D survey of sarno baths (Pompeii) by integrated geomatic methodologies. J. Cult. Herit. 2019, 40, 240-246. [CrossRef]

64. Li, L.; Cao, X.; He, Q.; Sun, J.; Jia, B.; Dong, X. A new 3D laser-scanning and GPS combined measurement system. Comptes Rendus Geosci. 2019, 351, 508-516. [CrossRef]

65. Fregonese, L.; Barbieri, G.; Biolzi, L.; Bocciarelli, M.; Frigeri, A.; Taffurelli, L. Surveying and monitoring for vulnerability assessment of an ancient building. Sensors 2013, 13, 9747-9773. [CrossRef]

66. Georgopoulos, G.D.; Telioni, E.C.; Tsontzou, A. The contribution of laser scanning technology in the estimation of ancient Greek monuments' deformations. Surv. Rev. 2016, 48, 303-308. [CrossRef]

67. Jaafar, H.A.; Meng, X.; Sowter, A.; Bryan, P. New approach for monitoring historic and heritage buildings: Using terrestrial laser scanning and generalised procrustes analysis. Struct. Control Health Monit. 2017, 24, e1987. [CrossRef]

68. Pesci, A.; Casula, G.; Boschi, E. Laser scanning the garisenda and asinelli towers in Bologna (Italy): Detailed deformation patterns of two ancient leaning buildings. J. Cult. Herit. 2011, 12, 117-127. [CrossRef]

69. Pesci, A.; Teza, G.; Bonali, E.; Casula, G.; Boschi, E. A laser scanning-based method for fast estimation of seismic-induced building deformations. ISPRS J. Photogramm. 2013, 79, 185-198. [CrossRef]

70. Pesci, A.; Bonali, E.; Galli, C.; Boschi, E. Laser scanning and digital imaging for the investigation of an ancient building: Palazzo d'Accursio study case (Bologna, Italy). J. Cult. Herit. 2012, 13, 215-220. [CrossRef]

71. Quagliarini, E.; Clini, P.; Ripanti, M. Fast, low cost and safe methodology for the assessment of the state of conservation of historical buildings from 3D laser scanning: The case study of Santa Maria in Portonovo (Italy). J. Cult. Herit. 2017, 24, 175-183. [CrossRef]

72. Tucci, G.; Bonora, V. Towers in San Gimignano: Metric survey approach. J. Perform. Constr. Facil. 2017, 31, 04017105. [CrossRef]

73. Tucci, G.; Conti, A.; Fiorini, L. Geomatics for structural assessment and surface diagnostic of CH. Procedia Struct. Integr. 2018, 11, 2-11. [CrossRef]

74. Batur, M.; Yilmaz, O.; Ozener, H. A case study of deformation measurements of Istanbul land walls via terrestrial laser scanning. IEEE J. Sel. Top. Appl. Earth Obs. Remote Sens. 2020, 13, 6362-6371. [CrossRef]

75. Costamagna, E.; Santana Quintero, M.; Bianchini, N.; Mendes, N.; Lourenço, P.B.; Su, S.; Paik, Y.M.; Min, A. Advanced nondestructive techniques for the diagnosis of historic buildings: The loka-hteik-pan temple in Bagan. J. Cult. Herit. 2020, 43, 108-117. [CrossRef]

76. Grazzini, A.; Chiabrando, F.; Foti, S.; Sammartano, G.; Spanò, A. A multidisciplinary study on the seismic vulnerability of St. Agostino church in Amatrice following the 2016 seismic sequence. Int. J. Archit. Herit. 2020, 14, 885-902. [CrossRef]

77. Teza, G.; Pesci, A.; Trevisani, S. Multisensor surveys of tall historical buildings in high seismic hazard areas before and during a seismic sequence. J. Cult. Herit. 2015, 16, 255-266. [CrossRef]

78. Armesto, J.; Roca-Pardiñas, J.; Lorenzo, H.; Arias, P. Modelling masonry arches shape using terrestrial laser scanning data and nonparametric methods. Eng. Struct. 2010, 32, 607-615. [CrossRef]

79. Chellini, G.; Nardini, L.; Pucci, B.; Salvatore, W.; Tognaccini, R. Evaluation of seismic vulnerability of Santa Maria Del Mar in Barcelona by an integrated approach based on terrestrial laser scanner and finite element modeling. Int. J. Archit. Herit. 2014, 8, 795-819. [CrossRef]

80. Castellazzi, G.; D’Altri, A.; Bitelli, G.; Selvaggi, I.; Lambertini, A. From laser scanning to finite element analysis of complex buildings by using a semi-automatic procedure. Sensors 2015, 15, 18360-18380. [CrossRef]

81. D'Altri, A.M.; Milani, G.; de Miranda, S.; Castellazzi, G.; Sarhosis, V. Stability analysis of leaning historic masonry structures. Automat. Constr. 2018, 92, 199-213. [CrossRef]

82. Korumaz, M.; Betti, M.; Conti, A.; Tucci, G.; Bartoli, G.; Bonora, V.; Korumaz, A.G.; Fiorini, L. An integrated terrestrial laser scanner (TLS), deviation analysis (DA) and finite element (FE) approach for health assessment of historical structures. A minaret case study. Eng. Struct. 2017, 153, 224-238. [CrossRef]

83. González-Jorge, H.; Gonzalez-Aguilera, D.; Rodriguez-Gonzalvez, P.; Arias, P. Monitoring biological crusts in civil engineering structures using intensity data from terrestrial laser scanners. Constr. Build. Mater. 2012, 31, 119-128. [CrossRef]

84. Pozo-Antonio, J.S.; Puente, I.; Pereira, M.F.C.; Rocha, C.S.A. Quantification and mapping of deterioration patterns on granite surfaces by means of mobile LiDAR data. Measurement 2019, 140, 227-236. [CrossRef]

85. Sánchez-Aparicio, L.J.; Del Pozo, S.; Ramos, L.F.; Arce, A.; Fernandes, F.M. Heritage site preservation with combined radiometric and geometric analysis of TLS data. Automat. Constr. 2018, 85, 24-39. [CrossRef]

86. Suchocki, C. Comparison of time-of-flight and phase-shift TLS intensity data for the diagnostics measurements of buildings. Materials 2020, 13, 353. [CrossRef]

87. Lerones, P.M.; Vélez, D.O.; Rojo, F.G.; Gómez-García-Bermejo, J.; Casanova, E.Z. Moisture detection in heritage buildings by 3D laser scanning. Stud. Conserv. 2016, 61, 46-54. [CrossRef] 
88. Suchocki, C.; Damięcka-Suchocka, M.; Katzer, J.; Janicka, J.; Rapiński, J.; Stałowska, P. Remote detection of moisture and bio-deterioration of building walls by time-of-flight and phase-shift terrestrial laser scanners. Remote Sens. 2020, 12, 1708. [CrossRef]

89. Suchocki, C.; Katzer, J. Terrestrial laser scanning harnessed for moisture detection in building materials-Problems and limitations. Automat. Constr. 2018, 94, 127-134. [CrossRef]

90. Wagner, W.; Ullrich, A.; Ducic, V.; Melzer, T.; Studnicka, N. Gaussian decomposition and calibration of a novel small-footprint full-waveform digitising airborne laser scanner. ISPRS J. Photogramm. 2006, 60, 100-112. [CrossRef]

91. Kashani, A.; Olsen, M.; Parrish, C.; Wilson, N. A review of LIDAR radiometric processing: From ad hoc intensity correction to rigorous radiometric calibration. Sensors 2015, 15, 28099-28128. [CrossRef]

92. Tan, K.; Cheng, X. Correction of incidence angle and distance effects on TLS intensity data based on reference targets. Remote Sens. 2016, 8, 251. [CrossRef]

93. Remondino, F.; Spera, M.G.; Nocerino, E.; Menna, F.; Nex, F. State of the art in high density image matching. Photogramm. Rec. 2014, 29, 144-166. [CrossRef]

94. Luhmann, T.; Robson, S.; Kyle, S.; Boehm, J. Close-Range Photogrammetry and 3D Imaging, 3rd ed.; De Gruyter: Berlin, Germany, 2019; pp. 123-274, ISBN 978-3-11-060725-3.

95. Westoby, M.J.; Brasington, J.; Glasser, N.F.; Hambrey, M.J.; Reynolds, J.M. 'Structure-from-motion' photogrammetry: A low-cost, effective tool for geoscience applications. Geomorphology 2012, 179, 300-314. [CrossRef]

96. Aicardi, I.; Chiabrando, F.; Maria Lingua, A.; Noardo, F. Recent trends in cultural heritage 3D survey: The photogrammetric computer vision approach. J. Cult. Herit. 2018, 32, 257-266. [CrossRef]

97. Fonstad, M.A.; Dietrich, J.T.; Courville, B.C.; Jensen, J.L.; Carbonneau, P.E. Topographic structure from motion: A new development in photogrammetric measurement. Earth Surf. Process. Landforms 2013, 38, 421-430. [CrossRef]

98. Martínez, S.; Ortiz, J.; Gil, M.L.; Rego, M.T. Recording complex structures using close range photogrammetry: The cathedral of Santiago De Compostela. Photogram Rec. 2013, 28, 375-395. [CrossRef]

99. Adami, A.; Fassi, F.; Fregonese, L.; Piana, M. Image-based techniques for the survey of mosaics in the St Mark's Basilica in Venice. Virtual Archaeol. Rev. 2018, 9, 1-20. [CrossRef]

100. Koutsoudis, A.; Vidmar, B.; Ioannakis, G.; Arnaoutoglou, F.; Pavlidis, G.; Chamzas, C. Multi-image 3D reconstruction data evaluation. J. Cult. Herit. 2014, 15, 73-79. [CrossRef]

101. Pirchio, D.; Walsh, K.Q.; Kerr, E.; Giongo, I.; Giaretton, M.; Weldon, B.D.; Ciocci, L.; Sorrentino, L. Integrated framework to structurally model unreinforced masonry Italian medieval churches from photogrammetry to finite element model analysis through heritage building information modeling. Eng. Struct. 2021, 241, 112439. [CrossRef]

102. Tucci, G.; Bonora, V.; Conti, A.; Fiorini, L. Benchmarking range-based and image-based techniques for digitizing a glazed Earthenware frieze. ISPRS Ann. Photogramm. Remote Sens. Spatial Inf. Sci. 2015, 2, 315-322. [CrossRef]

103. Tapinaki, S.; Skamantzari, M.; Chliverou, R.; Evgenikou, V.; Konidi, A.M.; Ioannatou, E.; Mylonas, A.; Georgopoulos, A. 3D image based geometric documentation of a medieval fortress. Int. Arch. Photogramm. Remote Sens. Spatial Inf. Sci. 2019, 42, 699-705. [CrossRef]

104. Kouimtzoglou, T.; Stathopoulou, E.K.; Agrafiotis, P.; Georgopoulos, A. Image-based 3D reconstruction data as an analysis and documentation tool for architects: The case of Plaka Bridge in Greece. Int. Arch. Photogramm. Remote Sens. Spatial Inf. Sci. 2017, 42, 391-397. [CrossRef]

105. Pérez-Gracia, V.; Di Capua, D.; Caselles, O.; Rial, F.; Lorenzo, H.; González-Drigo, R.; Armesto, J. Characterization of a Romanesque Bridge in Galicia (Spain). Int. J. Archit. Herit. 2011, 5, 251-263. [CrossRef]

106. Peña-Villasenín, S.; Gil-Docampo, M.; Ortiz-Sanz, J. 3-D modeling of historic façades using SFM photogrammetry metric documentation of different building types of a historic center. Int. J. Archit. Herit. 2017, 11, 871-890. [CrossRef]

107. Riveiro, B.; Caamaño, J.C.; Arias, P.; Sanz, E. Photogrammetric 3D modelling and mechanical analysis of masonry arches: An approach based on a discontinuous model of voussoirs. Automat. Constr. 2011, 20, 380-388. [CrossRef]

108. Abate, D. Built-heritage multi-temporal monitoring through photogrammetry and 2D/3D change detection algorithms. Stud. Conserv. 2019, 64, 423-434. [CrossRef]

109. Galantucci, R.A.; Fatiguso, F. Advanced damage detection techniques in historical buildings using digital photogrammetry and 3D surface anlysis. J. Cult. Herit. 2019, 36, 51-62. [CrossRef]

110. Jalón, M.L.; Chiachío, J.; Gil-Martín, L.M.; Hernández-Montes, E. Probabilistic identification of surface recession patterns in heritage buildings based on digital photogrammetry. J. Build. Eng. 2021, 34, 101922. [CrossRef]

111. Russo, M.; Carnevali, L.; Russo, V.; Savastano, D.; Taddia, Y. Modeling and deterioration mapping of façades in historical urban context by close-range ultra-lightweight UAVs photogrammetry. Int. J. Archit. Herit. 2019, 13, 549-568. [CrossRef]

112. Brunetaud, X.; Luca, L.D.; Janvier-Badosa, S.; Beck, K.; Al-Mukhtar, M. Application of digital techniques in monument preservation. Eur. J. Environ. Civ. Eng. 2012, 16, 543-556. [CrossRef]

113. Randazzo, L.; Collina, M.; Ricca, M.; Barbieri, L.; Bruno, F.; Arcudi, A.; La Russa, M.F. Damage indices and photogrammetry for decay assessment of stone-built cultural heritage: The case study of the San Domenico Church main entrance Portal (South Calabria, Italy). Sustainability 2020, 12, 5198. [CrossRef]

114. Rosina, E.; Grinzato, E. Infrared and thermal testing for conservation of historic buildings. Mater. Eval. 2001, 59, 942-954. 
115. Moropoulou, A.; Avdelidis, N.; Karoglou, M.; Delegou, E.; Alexakis, E.; Keramidas, V. Multispectral applications of infrared thermography in the diagnosis and protection of built cultural heritage. Appl. Sci. 2018, 8, 284. [CrossRef]

116. Modest, M.F. Radiative Heat Transfer, 3rd ed.; Academic Press: New York, NY, USA, 2013; ISBN 978-0-12-386944-9.

117. Vollmer, M.; Möllmann, K.-P. Infrared Thermal Imaging: Fundamentals, Research and Applications, 2nd ed.; Wiley-VCH Verlag GmbH \& Co. KGaA: Weinheim, Germany, 2018; ISBN 978-3-527-41351-5.

118. Corsi, C. History highlights and future trends of infrared sensors. J. Mod. Opt. 2010, 57, 1663-1686. [CrossRef]

119. Kirimtat, A.; Krejcar, O. A review of infrared thermography for the investigation of building envelopes: Advances and prospects. Energy Build. 2018, 176, 390-406. [CrossRef]

120. Gade, R.; Moeslund, T.B. Thermal cameras and applications: A survey. Mach. Vis. Appl. 2014, 25, 245-262. [CrossRef]

121. Carbonell-Rivera, J.P.; Heinz, S.; Berner, K.; Lerma, J.L. Thermographic documentation and 3D visualization of the Burjassot Silo-Yard: Processing and 3D visualization of FLIR One thermal images. In Responsibility for Cultural Heritage through Geomatics; Karlsruher geowissenschaftliche, Schriften; Reihe, B., Ed.; Vermessungswesen und Photogrammetrie; HsKA-IMM: Karlsruhe, Germany, 2019; pp. 31-38, ISBN 978-3-89063-109-7.

122. Adamopoulos, E.; Rinaudo, F.; Bovero, A. First assessments on heritage science oriented image-based modeling using low-cost modified and mobile cameras. Int. Arch. Photogramm. Remote Sens. Spatial Inf. Sci. 2019, 42, 23-30. [CrossRef]

123. Avdelidis, N.P.; Moropoulou, A. Emissivity considerations in building thermography. Energy Build. 2003, 35, 663-667. [CrossRef]

124. Barreira, E.; Almeida, R.M.S.F.; Simões, M.L. Emissivity of building materials for infrared measurements. Sensors 2021, $21,1961$. [CrossRef]

125. Bagavathiappan, S.; Lahiri, B.B.; Saravanan, T.; Philip, J.; Jayakumar, T. Infrared thermography for condition monitoring-A review. Infrared Phys. Technol. 2013, 60, 35-55. [CrossRef]

126. Panella, F.W.; Pirinu, A.; Dattoma, V. A brief review and advances of thermographic image-Processing methods for IRT inspection: A case of study on GFRP plate. Exp. Tech. 2020, 45, 429-443. [CrossRef]

127. Bogue, R. Sensors for condition monitoring: A review of technologies and applications. Sens. Rev. 2013, 33, 295-299. [CrossRef]

128. Usamentiaga, R.; Venegas, P.; Guerediaga, J.; Vega, L.; Molleda, J.; Bulnes, F. Infrared thermography for temperature measurement and nondestructive testing. Sensors 2014, 14, 12305-12348. [CrossRef]

129. Shepard, S.M. Introduction to active thermography for nondestructive evaluation. Anti-Corros. Methods Mater. 1997, 44, 236-239. [CrossRef]

130. Maierhofer, C.; Röllig, M.; Krankenhagen, R. Integration of active thermography into the assessment of cultural heritage buildings. J. Mod. Opt. 2010, 57, 1790-1802. [CrossRef]

131. Balaras, C.A.; Argiriou, A.A. Infrared thermography for building diagnostics. Energy Build. 2002, 34, 171-183. [CrossRef]

132. Avdelidis, N.P.; Moropoulou, A. Applications of infrared thermography for the investigation of historic structures. J. Cult. Herit. 2004, 5, 119-127. [CrossRef]

133. Bisegna, F.; Ambrosini, D.; Paoletti, D.; Sfarra, S.; Gugliermetti, F. A Qualitative method for combining thermal imprints to emerging weak points of ancient wall structures by passive infrared thermography-A case study. J. Cult. Herit. 2014, 15, 199-202. [CrossRef]

134. Maldague, X. Theory and Practice of Infrared Technology for Nondestructive Testing; Wiley Series in Microwave and Optical Engineering; Wiley: New York, NY, USA, 2001; ISBN 978-0-471-18190-3.

135. Brooke, C. Thermal imaging for the archaeological investigation of historic buildings. Remote Sens. 2018, 10, 1401. [CrossRef]

136. Esteve, S.T. Aplicación de la Termografía Infrarroja como ensayo no destructivo (END) en la restauración del patrimonio arquitectónico. Pap. Partal Rev. Restaur. Monum. 2016, 8, 69-82.

137. Finco, L.; Girotto, M.; Gomez Serito, M.; Volinia, M. Un contributo per la conoscenza della chiesa maggiore di Santa Giulitta: La termografia all'infrarosso per la lettura delle tessiture murarie e l'interpretazione delle fasi costruttive. In Un Paesaggio Medievale tra Piemonte e Liguria: Il Sito di Santa Giulitta e l'Alta Val Tanaro/a cura di Paolo Demeglio; Insegna del Giglio: Sesto Fiorentino, Italy, 2019; pp. 364-373, ISBN 978-88-7814-947-2.

138. Grinzato, E.; Bison, P.G.; Marinetti, S. Monitoring of ancient buildings by the thermal method. J. Cult. Herit. 2002, 3, 21-29. [CrossRef]

139. Kylili, A.; Fokaides, P.A.; Christou, P.; Kalogirou, S.A. Infrared thermography (IRT) applications for building diagnostics: A review. Appl. Energy 2014, 134, 531-549. [CrossRef]

140. Delegou, E.T.; Mourgi, G.; Tsilimantou, E.; Ioannidis, C.; Moropoulou, A. A multidisciplinary approach for historic buildings diagnosis: The case study of the Kaisariani monastery. Heritage 2019, 2, 1211-1232. [CrossRef]

141. Lerma, C.; Mas, Á.; Gil, E.; Vercher, J.; Torner, M.E. Quantitative analysis procedure for building materials in historic buildings by applying infrared thermography. Russ. J. Nondestruct. Test. 2018, 54, 601-609. [CrossRef]

142. Moropoulou, A.; Labropoulos, K.C.; Delegou, E.T.; Karoglou, M.; Bakolas, A. Nondestructive techniques as a tool for the protection of built cultural heritage. Constr. Build. Mater. 2013, 48, 1222-1239. [CrossRef]

143. De Freitas, S.S.; de Freitas, V.P.; Barreira, E. Detection of façade plaster detachments using infrared thermography-A nondestructive technique. Constr. Build. Mater. 2014, 70, 80-87. [CrossRef]

144. Moral Ruiz, C.; García Bueno, A.; Cultrone, G.; Almagro Gorbea, A. Análisis de alteraciones murarias y modificaciones relacionales en dos áreas del palacio de Pedro I del Alcázar de Sevilla mediante estudio documental y verificación termográfica. Arqueol. Arquitect. 2018, 68, 2. [CrossRef] 
145. Torres-González, M.; Alejandre, F.J.; Flores-Alés, V.; Calero-Castillo, A.I.; Blasco-López, F.J. Analysis of the state of conservation of historical plasterwork through visual inspection and non-destructive tests. The case of the upper frieze of the toledanos room (The Royal Alcázar of Seville, Spain). J. Build. Eng. 2021, 40, 102314. [CrossRef]

146. Volinia, M. Integration of qualitative and quantitative infrared surveys to study the plaster conditions of valentino castle. In Proc. SPIE 4020; Dinwiddie, R.B., LeMieux, D.H., Eds.; SPIE: Orlando, FL, USA, 30 March 2000; pp. 324-334.

147. Briceño, C.; Gonzales, M.; Yaya, C.; Moreira, S.; Aguilar, R. Preliminary structural diagnosis of the Sacsamarca Church in Peru using photogrammetry and IR thermography. In Structural Analysis of Historical Constructions: An Interdisciplinary Approach; Aguilar, R., Moreira, S., Pando, M.A., Ramos, L.F., Torrealva, D., Eds.; RILEM Bookseries; Springer International Publishing: Cham, Switzerland, 2019; pp. 2431-2438, ISBN 978-3-319-99441-3.

148. Paoletti, D.; Ambrosini, D.; Sfarra, S.; Bisegna, F. Preventive thermographic diagnosis of historical buildings for consolidation. J. Cult. Herit. 2013, 14, 116-121. [CrossRef]

149. Danese, M.; Demšar, U.; Masini, N.; Charlton, M. Investigating material decay of historic buidlings using visual analytics with multi-temporal infrared thermographic data. Archaeometry 2009, 52, 482-501. [CrossRef]

150. Gomes-Heras, M.; Martinez-Perez, L.; Fort, R.; Alvarez de Buergo, M. Decay assessment through thermographic analysis in architectural and archaeological heritage. In Proceedings of the Geophysical Research Abstracts; EGU2010-8596; EGU: Vienna, Austria, 2010; Volume 12.

151. İnce, İ; Bozdağ, A.; Tosunlar, M.B.; Hatır, M.E.; Korkanç, M. Determination of deterioration of the main facade of the ferit Paşa Cistern by nondestructive techniques (Konya, Turkey). Environ. Earth Sci. 2018, 77, 420. [CrossRef]

152. Garrido, I.; Lagüela, S.; Sfarra, S.; Solla, M. Algorithms for the automatic detection and characterization of pathologies in heritage elements from thermographic images. Int. Arch. Photogramm. Remote Sens. Spatial Inf. Sci. 2019, 42, 497-501. [CrossRef]

153. Grinzato, E.; Cadelano, G.; Bison, P. Moisture map by IR thermography. J. Mod. Opt. 2010, 57, 1770-1778. [CrossRef]

154. Lerma, J.L.; Cabrelles, M.; Portalés, C. Multitemporal thermal analysis to detect moisture on a building façade. Constr. Build. Mater. 2011, 25, 2190-2197. [CrossRef]

155. Martínez-Garrido, M.I.; Fort, R.; Gómez-Heras, M.; Valles-Iriso, J.; Varas-Muriel, M.J. A comprehensive study for moisture control in cultural heritage using non-Destructive techniques. J. Appl. Geophys. 2018, 155, 36-52. [CrossRef]

156. Barbosa, M.T.G.; Rosse, V.J.; Laurindo, N.G. Thermography evaluation strategy proposal due moisture damage on building facades. J. Build. Eng. 2021, 43, 102555. [CrossRef]

157. Glavaš, H.; Hadzima-Nyarko, M.; Buljan, I.H.; Barić, T. Locating hidden elements in walls of cultural heritage buildings by using infrared thermography. Buildings 2019, 9, 32. [CrossRef]

158. Ibarra-Castanedo, C.; Sfarra, S.; Klein, M.; Maldague, X. Solar loading thermography: Time-lapsed thermographic survey and advanced thermographic signal processing for the inspection of civil engineering and cultural heritage structures. Infrared Phys. Technol. 2017, 82, 56-74. [CrossRef]

159. Spodek, J.; Rosina, E. Application of infrared thermography to historic building investigation. J. Archit. Conserv. 2009, 15, 65-81. [CrossRef]

160. Avdelidis, N.P.; Moropoulou, A.; Theoulakis, P. Detection of water deposits and movement in porous materials by infrared imaging. Infrared Phys. Technol. 2003, 44, 183-190. [CrossRef]

161. Bergamo, O.; Campione, G.; Donadello, S.; Russo, G. In-situ NDT testing procedure as an integral part of failure analysis of historical masonry arch bridges. Eng. Fail. Anal. 2015, 57, 31-55. [CrossRef]

162. Clark, M.R.; McCann, D.M.; Forde, M.C. Application of Infrared Thermography to the Non-Destructive Testing of Concrete and Masonry Bridges. NDT E Int. 2003, 36, 265-275. [CrossRef]

163. Orbán, Z.; Gutermann, M. Assessment of masonry arch railway bridges using non-destructive in-situ testing methods. Eng. Struct. 2009, 31, 2287-2298. [CrossRef]

164. Sciuto, C.; Allios, D.; Bendoula, R.; Cocoual, A.; Gardel, M.-E.; Geladi, P.; Gobrecht, A.; Gorretta, N.; Guermeur, N.; Jay, S.; et al. Characterization of building materials by means of spectral remote sensing: The example of carcassonne's defensive wall (Aude, France). J. Archaeol. Sci. Rep. 2019, 23, 396-405. [CrossRef]

165. Del Pozo, S.; Sánchez-Aparicio, L.J.; Rodriguez-Gonzalvez, P.; Herrero-Pascual, J.; Muñoz-Nieto, A.; Gonzalez-Aguilera, D. Multispectral imaging: Fundamentals, principles and methods of damage assessment in constructions. In Nondestructive Techniques for the Evaluation of Structures and Infrastructure; Riveiro, B., Solla, M., Eds.; Structures \& Infrastructures Series; CRC Press: London, UK, 2016; pp. 139-166, ISBN 978-1-138-02810-4.

166. Del Pozo, S.; Rodríguez-Gonzálvez, P.; Sánchez-Aparicio, L.J.; Muñoz-Nieto, A.; Hernández-López, D.; Felipe-García, B.; González-Aguilera, D. Multispectral imaging in cultural heritage conservation. Int. Arch. Photogramm. Remote Sens. Spatial Inf. Sci. 2017, 42, 155-162. [CrossRef]

167. Adamopoulos, E.; Rinaudo, F. Combining multiband imaging, photogrammetric techniques, and FOSS GIS for affordable degradation mapping of stone monuments. Buildings 2021, 11, 304. [CrossRef]

168. Lerma, J.L.; Cabrelles, M.; Akasheh, T.S.; Haddad, N.A. Documentation of weathered architectural heritage with visible, near infrared, thermal and laser scanning data. Int. J. Herit. Digit. Era 2012, 1, 251-275. [CrossRef]

169. Meroño, J.E.; Perea, A.J.; Aguilera, M.J.; Laguna, A.M. Recognition of materials and damage on historical buildings using digital image classification. S. Afr. J. Sci. 2015, 111, 1-9. [CrossRef] 
170. Rahrig, M.; Drewello, R.; Lazzeri, A. Opto-technical monitoring-A standardized methodology to assess the treatment of historical stone surfaces. Int. Arch. Photogramm. Remote Sens. Spatial Inf. Sci. 2018, 42, 945-952. [CrossRef]

171. Valença, J.; Gonçalves, L.M.S.; Júlio, E. Damage assessment on concrete surfaces using multi-spectral image analysis. Constr. Build. Mater. 2013, 40, 971-981. [CrossRef]

172. Valença, J.; Dias-da-Costa, D.; Gonçalves, L.; Júlio, E.; Araújo, H. Automatic concrete health monitoring: Assessment and monitoring of concrete surfaces. Struct. Infrastr. Eng. 2014, 10, 1547-1554. [CrossRef]

173. Verhoeven, G. Imaging the invisible using modified digital still cameras for straightforward and low-cost archaeological nearinfrared photography. J. Archaeol. Sci. 2008, 35, 3087-3100. [CrossRef]

174. Falco, C.M. High resolution digital camera for infrared reflectography. Rev. Sci. Instrum. 2009, 80, 071301. [CrossRef]

175. Webb, E.K.; Robson, S.; MacDonald, L.; Garside, D.; Evans, R. Spectral and 3D cultural heritage documentation using a modified camera. Int. Arch. Photogramm. Remote Sens. Spatial Inf. Sci. 2018, 42, 1183-1190. [CrossRef]

176. Sánchez, J.; Quirós, E. Semiautomatic detection and classification of materials in historic buildings with low-cost photogrammetric equipment. J. Cult. Herit. 2017, 25, 21-30. [CrossRef]

177. Daniels, D.J. Ground penetrating radar. In Encyclopedia of RF and Microwave Engineering; Chang, K., Ed.; John Wiley \& Sons, Inc.: Hoboken, NJ, USA, 2005; pp. 1833-1846, ISBN 978-0-471-65450-6.

178. Persico, R. Introduction to Ground Penetrating Radar: Inverse Scattering and Data Processing; WileyPress: Hoboken, NJ, USA, 2014; ISBN 978-1-118-83568-5.

179. Ground Penetrating Radar; Daniels, D.J. (Eds.) Institution of Engineering and Technology; Ground Penetrating Radar: London, UK, 2004; ISBN 978-0-86341-360-5.

180. Martinho, E.; Dionísio, A. Main geophysical techniques used for non-destructive evaluation in cultural built heritage: A review. J. Geophys. Eng. 2014, 11, 053001. [CrossRef]

181. Nobes, D.C.; Deng, J. Ground penetrating radar resolution in archaeological geophysics. In Archaeogeophysics; El-Qady, G., Metwaly, M., Eds.; Natural Science in Archaeology; Springer International Publishing: Cham, Switzerland, 2019; pp. 183-204, ISBN 978-3-319-78860-9.

182. Blake, V.S. Image processing and interpretation of ground penetrating radar data. Bar Int. Ser. 1995, 600, 175-180.

183. Annan, A.P. Electromagnetic principles of ground penetrating radar. In Ground Penetrating Radar: Theory and Applications; Jol, H.M., Ed.; Elsevier Science: Amsterdam, The Netherlands, 2009; pp. 3-40, ISBN 978-0-444-53348-7.

184. Solla, M.; Lorenzo, H.; Pérez-Gracia, V. Ground penetrating radar: Fundamentals, methodologies and applications in structures and infrastructure. In Non-Destructive Techniques for the Evaluation of Structures and Infrastructure; Riveiro, B., Solla, M., Eds.; Structures \& Infrastructures; CRC Press: London, UK, 2016; pp. 89-111, ISBN 978-0-429-22621-2.

185. Linford, N. The Application of geophysical methods to archaeological prospection. Rep. Prog. Phys. 2006, 69, 2205-2257. [CrossRef]

186. Morris, I.; Abdel-Jaber, H.; Glisic, B. Quantitative attribute analyses with ground penetrating radar for infrastructure assessments and structural health monitoring. Sensors 2019, 19, 1637. [CrossRef]

187. Nuzzo, L.; Leucci, G.; Negri, S.; Carrozzo, M.T.; Quarta, T. Application of 3D visualization techniques in the analysis of GPR data for archaeology. Ann. Geophys. 2002, 45, 321-337. [CrossRef]

188. Ortega-Ramírez, J.; Bano, M.; Villa Alvarado, L.A.; Medellín Martínez, D.; Rivero-Chong, R.; Motolinía-Temol, C.L. HighResolution 3-D GPR Applied in the Diagnostic of the Detachment and Cracks in Pre-Hispanic Mural Paintings at "Templo Rojo", Cacaxtla, Tlaxcala, Mexico. J. Cult. Herit. 2021, 50, 61-72. [CrossRef]

189. Lualdi, M.; Zanzi, L.; Binda, L. Acquisition and processing requirements for high quality 3D reconstructions from GPR investigations. In Proceedings of the Non-Destructive Testing in Civil Engineering, Berlin, Germany, 16-19 September 2003.

190. Novo, A. Ground-penetrating radar (GPR). In Good Practice in Archaeological Diagnostics; Corsi, C., Slapšak, B., Vermeulen, F., Eds.; Natural Science in Archaeology; Springer International Publishing: Cham, Switzerland, 2013; pp. 165-176, ISBN 978-3-319-01783-9.

191. Utsi, E.C. Ground Penetrating Radar, 1st ed.; Elsevier: Boston, MA, USA, 2017; pp. 105-116, ISBN 978-0-08-102216-0.

192. Binda, L.; Lualdi, M.; Saisi, A.; Zanzi, L. Radar investigation as a complementary tool for the diagnosis of historic masonry buildings. Int. J. Mater. Struct. Integr. 2011, 5, 1. [CrossRef]

193. Binda, L.; Saisi, A.; Tiraboschi, C.; Valle, S.; Colla, C.; Forde, M. Application of sonic and radar tests on the piers and walls of the cathedral of noto. Constr. Build. Mater. 2003, 17, 613-627. [CrossRef]

194. Deiana, R. The contribution of geophysical prospecting to the multidisciplinary study of the Sarno Baths, Pompeii. J. Cult. Herit. 2019, 40, 274-279. [CrossRef]

195. Işık, N.; Halifeoğlu, F.M.; İpek, S. Nondestructive testing techniques to evaluate the structural damage of historical city walls. Constr. Build. Mater. 2020, 253, 119228. [CrossRef]

196. Lachowicz, J.; Rucka, M. Diagnostics of Pillars in St. Mary's Church (Gdańsk, Poland) using the GPR method. Int. J. Arch. Herit. 2019, 13, 1223-1233. [CrossRef]

197. Lampropoulos, K.C.; Moropoulou, A.; Korres, M. Ground penetrating radar prospection of the construction phases of the holy aedicula of the holy sepulchre in correlation with architectural analysis. Constr. Build. Mater. 2017, 155, 307-322. [CrossRef]

198. Leucci, G.; Masini, N.; Persico, R. Time-frequency analysis of GPR data to investigate the damage of monumental buildings. J. Geophys. Eng. 2012, 9, S81-S91. [CrossRef] 
199. Ludeno, G.; Cavalagli, N.; Ubertini, F.; Soldovieri, F.; Catapano, I. On the combined use of ground penetrating radar and crack meter sensors for structural monitoring: Application to the historical Consoli Palace in Gubbio, Italy. Surv. Geophys. 2020, 41, 647-667. [CrossRef]

200. Masini, N.; Nuzzo, L.; Rizzo, E. GPR Investigations for the study and the restoration of the rose window of Troia cathedral (Southern Italy). Near Surf. Geophys. 2007, 5, 287-300. [CrossRef]

201. Orlando, L.; Slob, E. Using multicomponent GPR to monitor cracks in a historical building. J. Appl. Geophys. 2009, 67, 327-334. [CrossRef]

202. Pérez-Gracia, V.; García, F.; Pujades, L.G.; González Drigo, R.; Di Capua, D. GPR survey to study the restoration of a Roman monument. J. Cult. Herit. 2008, 9, 89-96. [CrossRef]

203. Ranalli, D.; Scozzafava, M.; Tallini, M. Ground penetrating radar investigations for the restoration of historic buildings: The case study of the Collemaggio Basilica (L'Aquila, Italy). J. Cult. Herit. 2004, 5, 91-99. [CrossRef]

204. Solla, M.; Lorenzo, H.; Novo, A.; Rial, F.I. Ground-penetrating radar assessment of the medieval arch bridge of San Antón, Galicia, Spain. Archaeol. Prospect. 2010, 17, 223-232. [CrossRef]

205. Barone, P.M.; Di Matteo, A.; Graziano, F.; Mattei, E.; Pettinelli, E. GPR Application to the structural control of historical buildings: Two case studies in Rome, Italy. Near Surf. Geophys. 2010, 8, 407-413. [CrossRef]

206. Labropoulos, K.; Moropoulou, A. Ground penetrating radar investigation of the bell tower of the church of the Holy Sepulchre. Constr. Build. Mater. 2013, 47, 689-700. [CrossRef]

207. Leucci, G.; Cataldo, R.; De Nunzio, G. Assessment of fractures in some columns inside the crypt of the cattedrale Di Otranto using integrated geophysical methods. J. Archaeol. Sci. 2007, 34, 222-232. [CrossRef]

208. Johnston, B.; Ruffell, A.; McKinley, J.; Warke, P. Detecting voids within a historical building façade: A comparative study of three high frequency GPR Antenna. J. Cult. Herit. 2018, 32, 117-123. [CrossRef]

209. Barraca, N.; Almeida, M.; Varum, H.; Almeida, F.; Matias, M.S. A case study of the use of GPR for rehabilitation of a classified art deco building: The inovadomus house. J. Appl. Geophys. 2016, 127, 1-13. [CrossRef]

210. Leucci, G.; Cataldo, R.; De Nunzio, G. Subsurface water-content identification in a crypt using GPR and comparison with microclimatic conditions. Near Surf. Geophys. 2006, 4, 207-213. [CrossRef]

211. Masini, N.; Persico, R.; Rizzo, E. Some examples of GPR prospecting for monitoring of the monumental heritage. J. Geophys. Eng. 2010, 7, 190-199. [CrossRef]

212. Kanli, A.I.; Taller, G.; Nagy, P.; Tildy, P.; Pronay, Z.; Toros, E. GPR survey for reinforcement of historical heritage construction at fire tower of sopron. J. Appl. Geophys. 2015, 112, 79-90. [CrossRef]

213. Rucka, M.; Lachowicz, J.; Zielińska, M. GPR Investigation of the strengthening system of a historic masonry tower. J. Appl. Geophys. 2016, 131, 94-102. [CrossRef]

214. Pieraccini, M.; Noferini, L.; Mecatti, D.; Luzi, G.; Atzeni, C.; Persico, R.; Soldovieri, F. Advanced processing techniques for step-frequency continuous-wave penetrating radar: The case study of "Palazzo Vecchio" Walls (Firenze, Italy). Res. Nondestr. Eval. 2006, 17, 71-83. [CrossRef]

215. Solla, M.; Lagüela, S.; Riveiro, B.; Lorenzo, H. Non-Destructive Testing for the Analysis of Moisture in the Masonry Arch Bridge of Lubians (Spain). Struct. Control Health Monit. 2013, 20, 1366-1376. [CrossRef]

216. Alani, A.M.; Tosti, F.; Ciampoli, L.B.; Gagliardi, V.; Benedetto, A. An integrated investigative approach in health monitoring of masonry arch bridges using GPR and InSAR technologies. NDT E Int. 2020, 115, 102288. [CrossRef]

217. Solla, M.; Lorenzo, H.; Rial, F.I.; Novo, A. GPR evaluation of the roman masonry arch bridge of Lugo (Spain). NDT E Int. 2011, 44, 8-12. [CrossRef]

218. Bautista-De Castro, Á.; Sánchez-Aparicio, L.J.; Carrasco-García, P.; Ramos, L.F.; González-Aguilera, D. A Multidisciplinary Approach to Calibrating Advanced Numerical Simulations of Masonry Arch Bridges. Mech. Syst. Signal Process. 2019, 129, 337-365. [CrossRef]

219. Solla, M.; Asorey-Cacheda, R.; Núñez-Nieto, X.; Conde-Carnero, B. Evaluation of historical bridges through recreation of GPR models with the FDTD algorithm. NDT E Int. 2016, 77, 19-27. [CrossRef]

220. Solla, M.; Lorenzo, H.; Rial, F.I.; Novo, A. Ground-Penetrating Radar for the Structural Evaluation of Masonry Bridges: Results and Interpretational Tools. Constr. Build. Mater. 2012, 29, 458-465. [CrossRef]

221. Helmerich, R.; Niederleithinger, E.; Trela, C.; Bień, J.; Kamiński, T.; Bernardini, G. Multi-Tool Inspection and Numerical Analysis of an Old Masonry Arch Bridge. Struct. Infrastruct. Eng. 2012, 8, 27-39. [CrossRef]

222. Russo, S. Integrated assessment of monumental structures through ambient vibrations and ND tests: The case of Rialto Bridge. J. Cult. Herit. 2016, 19, 402-414. [CrossRef]

223. Oliveira, D.V.; Allahvirdizadeh, R.; Sánchez, A.; Riveiro, B.; Mendes, N.; Silva, R.A.; Fernandes, F.M. Assessment of a Medieval Arch Bridge Resorting to Non-destructive Techniques and Numerical Tools. In Proceedings of ARCH 2019; Arêde, A., Costa, C., Eds.; Structural Integrity; Springer International Publishing: Cham, Switzerland, 2020; Volume 11, pp. 464-472, ISBN 978-3-030-29226-3.

224. Solla, M.; Lorenzo, H.; Novo, A.; Riveiro, B. Evaluation of ancient structures by GPR (ground penetrating radar): The arch bridges of Galicia (Spain). Sci. Res. Essays 2011, 6, 1877-1884. [CrossRef] 
225. Trela, C.; Wöstmann, J.; Kruschwitz, S. Contribution of radar measurements to the inspection and condition assessment of railway bridges-Case study at a historic masonry arch bridge in Oleśnica/Poland. In Proceedings of the High Performance Structures and Materials IV; WIT Press: Algarve, Portugal, 2008; Volume 1, pp. 535-544.

226. Miranda, L.; Cantini, L.; Guedes, J.; Costa, A. Assessment of mechanical properties of full-scale masonry panels through sonic methods. Comparison with mechanical destructive tests: Experimental sonic test on stone masonry. Struct. Control Health Monit. 2016, 23, 503-516. [CrossRef]

227. Concu, G.; De Nicolo, B.; Valdes, M. Prediction of building limestone physical and mechanical properties by means of ultrasonic P-wave velocity. Sci. World J. 2014, 2014, 508073. [CrossRef]

228. Rodríguez-Mariscal, J.D.; Canivell, J.; Solís, M. Evaluating the performance of sonic and ultrasonic tests for the inspection of rammed Earth constructions. Constr. Build. Mater. 2021, 299, 123854. [CrossRef]

229. Luchin, G.; Ramos, L.F.; D’Amato, M. Sonic tomography for masonry walls characterization. Int. J. Archit. Herit. 2020, 14, 589-604. [CrossRef]

230. Manning, E.; Ramos, L.F.; Fernandes, F.M. Direct Sonic and Ultrasonic Wave Velocity in Masonry under Compressive Stress; International Masonry Society: Guimarães, Portugal, 2014.

231. Binda, L.; Saisi, A.; Tiraboschi, C. Investigation procedures for the diagnosis of historic masonries. Constr. Build. Mater. 2000, 14, 199-233. [CrossRef]

232. Binda, L.; Saisi, A.; Tiraboschi, C. Application of sonic tests to the diagnosis of damaged and repaired structures. NDT E Int. 2001, 34, 123-138. [CrossRef]

233. Pérez-Gracia, V.; Fontul, S.; Santos-Asssunçao, S.; Marecos, V. Geophysics: Fundamentals and applications in structures and infrastructure. In Non-Destructive Techniques for the Evaluation of Structures and Infrastructure; Riveiro, B., Solla, M., Eds.; Structures \& Infrastructures Series; CRC Press/Balkema: Leiden, The Netherlands, 2016; pp. 59-88, ISBN 978-1-138-02810-4.

234. Leucci, G. Nondestructive testing technologies for cultural heritage: Overview. In Nondestructive Testing for Archaeology and Cultural Heritage; Springer International Publishing: Cham, Switzerland, 2019; pp. 15-73, ISBN 978-3-030-01898-6.

235. Bozdağ, A.; İnce, İ.; Bozdağ, A.; Hatır, M.E.; Tosunlar, M.B.; Korkanç, M. An assessment of deterioration in cultural heritage: The unique case of eflatunpinar hittite water monument in Konya, Turkey. Bull. Eng. Geol. Environ. 2020, 79, 1185-1197. [CrossRef]

236. Fais, S.; Casula, G.; Cuccuru, F.; Ligas, P.; Bianchi, M.G. An innovative methodology for the non-destructive diagnosis of architectural elements of ancient historical buildings. Sci. Rep. 2018, 8, 4334. [CrossRef]

237. Fais, S.; Cuccuru, F.; Ligas, P.; Casula, G.; Bianchi, M.G. Integrated ultrasonic, laser scanning and petrographical characterisation of carbonate building materials on an architectural structure of a historic building. Bull. Eng. Geol. Environ. 2017, 76, 71-84. [CrossRef]

238. Grazzini, A.; Fasana, S.; Zerbinatti, M.; Lacidogna, G. Non-destructive tests for damage evaluation of stone columns: The case study of Sacro Monte in Ghiffa (Italy). Appl. Sci. 2020, 10, 2673. [CrossRef]

239. Hatır, M.E.; Korkanç, M.; Başar, M.E. Evaluating the deterioration effects of building stones using NDT: The Küçükköy Church, Cappadocia Region, Central Turkey. Bull. Eng. Geol. Environ. 2019, 78, 3465-3478. [CrossRef]

240. Karanikoloudis, G.; Lourenço, P.B. Structural assessment and seismic vulnerability of earthen historic structures. Application of sophisticated numerical and simple analytical models. Eng. Struct. 2018, 160, 488-509. [CrossRef]

241. Mesquita, E.; Martini, R.; Alves, A.; Antunes, P.; Varum, H. Non-destructive characterization of ancient clay brick walls by indirect ultrasonic measurements. J. Build. Eng. 2018, 19, 172-180. [CrossRef]

242. Salvatici, T.; Calandra, S.; Centauro, I.; Pecchioni, E.; Intrieri, E.; Garzonio, C.A. Monitoring and evaluation of sandstone decay adopting non-destructive techniques: On-site application on building stones. Heritage 2020, 3, 1287-1301. [CrossRef]

243. Tosunlar, M.B.; Beycan, A.D.; Korkanç, M. Non-destructive test investigations on the deterioration of roman mausoleum in Karadağ central anatolia, Turkey. Mediterr. Archaeol. Archaeom. 2020, 20, 199-219.

244. Klein, L.A. Sensor and Data Fusion: A Tool for Information Assessment and Decision Making; SPIE: Bellingham, WA, USA, 2004; ISBN 978-0-8194-5435-5.

245. Ramos, M.M.; Remondino, F. Data fusion in cultural heritage-A review. Int. Arch. Photogramm. Remote Sens. Spatial Inf. Sci. 2015, 40, 359-363. [CrossRef]

246. Adamopoulos, E.; Rinaudo, F. 3D interpretation and fusion of multidisciplinary data for heritage science: A review. Int. Arch. Photogramm. Remote Sens. Spatial Inf. Sci. 2019, 42, 17-24. [CrossRef]

247. Oliveira, A.; Oliveira, J.F.; Pereira, J.M.; de Araújo, B.R.; Boavida, J. 3D modelling of laser scanned and photogrammetric data for digital documentation: The Mosteiro Da Batalha case study. J. Real-Time Image Proc. 2014, 9, 673-688. [CrossRef]

248. Croce, V.; Caroti, G.; Piemonte, A.; Bevilacqua, M.G. Geomatics for cultural heritage conservation: Integrated survey and 3D modeling. In Proceedings of the 2019 IMEKO TC-4 International Conference on Metrology for Archaeology and Cultural Heritage (2019 MetroArchaeo), Florence, Italy, 4-6 December 2019; Catelani, M., Daponte, P., Eds.; IMEKO: Florence, Italy, 2019; pp. 271276. Available online: https:/ / www.imeko.org/publications/tc4-Archaeo-2019/IMEKO-TC4-METROARCHAEO-2019-50.pdf (accessed on 27 September 2021).

249. Chiabrando, F.; Sammartano, G.; Spanò, A.; Spreafico, A. Hybrid 3D models: When geomatics innovations meet extensive built heritage complexes. ISPRS Int. J. Geoinf. 2019, 8, 124. [CrossRef]

250. Alshawabkeh, Y. Color and laser data as a complementary approach for heritage documentation. Remote Sens. 2020, $12,3465$. [CrossRef] 
251. Muñumer, E.; Lerma, J.L. Fusion of 3D data from different image-based and range-based sources for efficient heritage recording. In Proceedings of the 2015 Digital Heritage, Granada, Spain, 28 September-2 October 2015; IEEE: Granada, Spain, 2015; pp. 83-86.

252. Altuntas, C.; Yildiz, F.; Scaioni, M. Laser scanning and data integration for three-dimensional digital recording of complex historical structures: The case of Mevlana Museum. ISPRS Int. J. Geoinf. 2016, 5, 18. [CrossRef]

253. Shanoer, M.M.; Abed, F.M. Evaluate 3D laser point clouds registration for cultural heritage documentation. Egypt. J. Remote Sens. Space Sci. 2018, 21, 295-304. [CrossRef]

254. Tombari, F.; Remondino, F. Feature-Based Automatic 3D Registration for Cultural Heritage Applications.; IEEE: Marseille, France, $2013 ;$ pp. 55-62.

255. Costanzo, A.; Pisciotta, A.; Pannaccione Apa, M.I.; Bongiovanni, S.; Capizzi, P.; D'Alessandro, A.; Falcone, S.; La Piana, C.; Martorana, R. Integrated use of unmanned aerial vehicle photogrammetry and terrestrial laser scanning to support archaeological analysis: The Acropolis of Selinunte case (Sicily, Italy). Archaeol. Prospect. 2021, 28, 153-165. [CrossRef]

256. Jo, Y.; Hong, S. Three-dimensional digital documentation of cultural heritage site based on the convergence of terrestrial laser scanning and unmanned aerial vehicle photogrammetry. ISPRS Int. J. Geoinf. 2019, 8, 53. [CrossRef]

257. Liang, H.; Li, W.; Lai, S.; Zhu, L.; Jiang, W.; Zhang, Q. The integration of terrestrial laser scanning and terrestrial and unmanned aerial vehicle digital photogrammetry for the documentation of Chinese classical gardens-A case study of Huanxiu Shanzhuang, Suzhou, China. J. Cult. Herit. 2018, 33, 222-230. [CrossRef]

258. Ulvi, A. Documentation, three-dimensional (3D) modelling and visualization of cultural heritage by using unmanned aerial vehicle (UAV) photogrammetry and terrestrial laser scanners. Int. J. Remote Sens. 2021, 42, 1994-2021. [CrossRef]

259. Xu, Z.; Wu, L.; Shen, Y.; Li, F.; Wang, Q.; Wang, R. Tridimensional reconstruction applied to cultural heritage with the use of camera-equipped UAV and terrestrial laser scanner. Remote Sens. 2014, 6, 10413-10434. [CrossRef]

260. Zitová, B.; Flusser, J. Image registration methods: A survey. Image Vis. Comput. 2003, 21, 977-1000. [CrossRef]

261. Lerma, J.L.; Akasheh, T.S.; Haddad, N.A.; Cabrelles, M. Multispectral sensors in combination with recording tools for cultural heritage documentation. Chang. Over Time 2011, 1, 236-250.

262. Sánchez-Aparicio, L.J.; Del Pozo, S.; Rodriguez-Gonzalvez, P.; Herrero-Pascual, J.; Muñoz-Nieto, A.; Gonzalez-Aguilera, D. Practical use of multispectral techniques for the detection of pathologies in constructions. In Non-Destructive Techniques for the Evaluation of Structures and Infrastructure; Riveiro, B., Solla, M., Eds.; Structures \& Infrastructures Series; CRC Press: London, UK, 2016; pp. 253-271, ISBN 978-1-138-02810-4.

263. Del Pozo, S.; Herrero-Pascual, J.; Felipe-García, B.; Hernández-López, D.; Rodríguez-Gonzálvez, P.; González-Aguilera, D. Multispectral radiometric analysis of façades to detect pathologies from active and passive remote sensing. Remote Sens. 2016, 8, 80. [CrossRef]

264. Conde, B.; Del Pozo, S.; Riveiro, B.; González-Aguilera, D. Automatic mapping of moisture affectation in exposed concrete structures by fusing different wavelength remote sensors. Struct. Control Health Monit. 2016, 23, 923-937. [CrossRef]

265. Bitelli, G.; Barbieri, E.; Girelli, V.A.; Lambertini, A.; Mandanici, E.; Melandri, E.; Roggio, D.S.; Santangelo, A.; Tini, M.A.; Tondelli, S.; et al. The complex of Santa Croce in Ravenna as a case study: Integration of 3D techniques for surveying and monitoring of a historical site. In Proceedings of the ARQUEOLÓGICA 2.0-9th International Congress \& 3rd GEORES-GEOmatics and pREServation, Valéncia, Spain, 26-28 April 2021; pp. 408-413.

266. Rizzi, A.; Voltolini, F.; Girardi, S.; Gonzo, L.; Remondino, F. Digital presentation, documentation and analysis of paintings, monuments and large cultural heritage with infrared technology, digital cameras and range sensors. Int. Arch. Photogramm. Remote Sens. Spatial Inf. Sci. 2007, 36, 3-8.

267. Mizginov, V.A.; Kniaz, V.V. Evaluating the accuracy of 3D object reconstruction from thermal images. Int. Arch. Photogramm. Remote Sens. Spatial Inf. Sci. 2019, 42, 129-134. [CrossRef]

268. Adamopoulos, E.; Patrucco, G.; Volinia, M.; Girotto, M.; Rinaudo, F.; Tonolo, F.G.; Spanò, A. 3D thermal mapping of architectural heritage: Up-to-date workflows for the production of three-dimensional thermographic models for built heritage NDT. In Digital Heritage. Progress in Cultural Heritage: Documentation, Preservation, and Protection; Ioannides, M., Fink, E., Cantoni, L., Eds.; Lecture Notes in Computer Science; Springer International Publishing: Cham, Switzeralnd, 2021; Volume 12642, pp. 26-37, ISBN 978-3-030-73042-0.

269. González-Aguilera, D.; Lagüela, S.; Rodríguez-Gonzálvez, P.; Hernández-López, D. Image-based thermographic modeling for assessing energy efficiency of buildings façades. Energy Build. 2013, 65, 29-36. [CrossRef]

270. Dlesk, A.; Vach, K.; Holubec, P. Usage of photogrammetric processing of thermal images for civil engineers. Int. Arch. Photogramm. Remote Sens. Spatial Inf. Sci. 2018, 42, 99-103. [CrossRef]

271. Patrucco, G.; Cortese, G.; Giulio Tonolo, F.; Spanò, A. Thermal and optical data fusion supporting built heritage analyses. Int. Arch. Photogramm. Remote Sens. Spatial Inf. Sci. 2020, 43, 619-626. [CrossRef]

272. Previtali, M.; Barazzetti, L.; Redaelli, V.; Scaioni, M.; Rosina, E. Rigorous procedure for mapping thermal infrared images on three-dimensional models of building façades. J. Appl. Remote Sens. 2013, 7, 073503. [CrossRef]

273. Hoegner, L.; Stilla, U. Mobile thermal mapping for matching of infrared images with 3D building models and 3D point clouds. Quant. InfraRed Thermogr. J. 2018, 1-19. [CrossRef]

274. Macher, H.; Boudhaim, M.; Grussenmeyer, P.; Siroux, M.; Landes, T. Combination of thermal and geometric information for BIM enrichment. Int. Arch. Photogramm. Remote Sens. Spatial Inf. Sci. 2019, 42, 719-725. [CrossRef]

275. Dino, I.G.; Sari, A.E.; Iseri, O.K.; Akin, S.; Kalfaoglu, E.; Erdogan, B.; Kalkan, S.; Alatan, A.A. Image-based construction of building energy models using computer vision. Automat. Constr. 2020, 116, 103231. [CrossRef] 
276. Spanò, A.; Volinia, M.; Girotto, M. Spatial data and temperature: Relationship to deepen. Integrated methods for advanced architectural diagnosis and metric documentation. In Proceedings of the Eight Internation Conference on Non'Destructive Investigations and Microanalysis for the Diagnostics and Conservation of the Cultural and Environmental Heritage, Lecce, Italy, 15-19 May 2005; Marabelli, M., Parisi, C., Buzzanca, G., Paradisi, A., Eds.; Italian Society of Non-Destructive Testing Monitoring Diagnostics AIPnD: Lecce, Italy, 2005.

277. Zalama, E.; Gómez-García-Bermejo, J.; Llamas, J.; Medina, R. An effective texture mapping approach for 3D models obtained from laser scanner data to building documentation: An effective texture mapping approach. Comput.-Aided Civil Infrastr. Eng. 2011, 26, 381-392. [CrossRef]

278. Costanzo, A.; Minasi, M.; Casula, G.; Musacchio, M.; Buongiorno, M. Combined use of terrestrial laser scanning and IR thermography applied to a historical building. Sensors 2014, 15, 194-213. [CrossRef]

279. Mileto, C.; Vegas, F.; Lerma, J.L. Multidisciplinary studies, crossreading and transversal use of thermography: The castle of Monzón (Huesca) as a case study. In Proceedings of the Modern Age Fortifications of the Mediterranean Coast-Defensive Architecture of the Mediterranean (Fortmed2015), Valéncia, Spain, 15-17 October 2015; Editorial Universitat Politècnica de València, Ed.; Editorial Universitat Politècnica de València: Valéncia, Spain, 2015.

280. Lagüela, S.; Díaz-Vilariño, L.; Martínez, J.; Armesto, J. Automatic thermographic and RGB texture of as-built BIM for energy rehabilitation purposes. Automat. Constr. 2013, 31, 230-240. [CrossRef]

281. González-Aguilera, D.; Rodriguez-Gonzalvez, P.; Armesto, J.; Lagüela, S. Novel approach to 3D thermography and energy efficiency evaluation. Energy Build. 2012, 54, 436-443. [CrossRef]

282. Alba, M.I.; Barazzetti, L.; Scaioni, M.; Rosina, E.; Previtali, M. Mapping infrared data on terrestrial laser scanning 3D models of buildings. Remote Sens. 2011, 3, 1847-1870. [CrossRef]

283. Borrmann, D.; Elseberg, J.; Nüchter, A. Thermal 3D mapping of building façades. In Intelligent Autonomous Systems 12; Lee, S., Cho, H., Yoon, K.-J., Lee, J., Eds.; Advances in Intelligent Systems and Computing; Springer: Berlin/Heidelberg, Germany, 2013; Volume 193, pp. 173-182, ISBN 978-3-642-33925-7.

284. Merchán, P.; Merchán, M.J.; Salamanca, S.; Adán, A. Application of multisensory technology for resolution of problems in the field of research and preservation of cultural heritage. In Advances in Digital Cultural Heritage; Ioannides, M., Martins, J., Žarnić, R., Lim, V., Eds.; Lecture Notes in Computer Science; Springer International Publishing: Cham, Switzeralnd, 2018; Volume 10754, pp. 32-47, ISBN 978-3-319-75788-9.

285. Yang, M.-D.; Su, T.-C.; Lin, H.-Y. Fusion of infrared thermal image and visible image for 3D thermal model reconstruction using smartphone sensors. Sensors 2018, 18, 2003. [CrossRef]

286. Lin, D.; Jarzabek-Rychard, M.; Tong, X.; Maas, H.-G. Fusion of thermal imagery with point clouds for building façade thermal attribute mapping. ISPRS J. Photogramm. Remote Sens. 2019, 151, 162-175. [CrossRef]

287. Sahin, C.D.; Mengüç, M.P. Image registration method for mobile-device-based multispectral optical diagnostics for buildings. Appl. Opt. 2019, 58, 7165. [CrossRef] [PubMed]

288. Adán, A.; Pérez, V.; Vivancos, J.-L.; Aparicio-Fernández, C.; Prieto, S.A. Proposing 3D thermal technology for heritage building energy monitoring. Remote Sens. 2021, 13, 1537. [CrossRef]

289. Coret, L.; Briottet, X.; Kerr, Y.H.; Chehbouni, A. Simulation study of view angle effects on thermal infrared measurements over heterogeneous surfaces. IEEE Trans. Geosci. Remote Sens. 2004, 42, 664-672. [CrossRef]

290. Adamopoulos, E.; Colombero, C.; Comina, C.; Rinaudo, F.; Volinia, M.; Girotto, M.; Ardissono, L. Integrating multiband photogrammetry, scanning, and GPR for built heritage surveys: The façades of Castello Del Valentino. ISPRS Ann. Photogramm. Remote Sens. Spatial Inf. Sci. 2021, 8, 1-8. [CrossRef]

291. Garrido, I.; Solla, M.; Lagüela, S.; Fernández, N. IRT and GPR Techniques for moisture detection and characterisation in buildings. Sensors 2020, 20, 6421. [CrossRef]

292. Moselhi, O.; Ahmed, M.; Bhowmick, A. Multisensor data fusion for bridge condition assessment. J. Perform. Constr. Facil. 2017, 31, 04017008. [CrossRef]

293. Pérez, J.; de Sanjosé Blasco, J.; Atkinson, A.; del Río Pérez, L. Assessment of the structural integrity of the roman bridge of alcántara (Spain) using TLS and GPR. Remote Sens. 2018, 10, 387. [CrossRef]

294. Cozzolino, M.; Di Meo, A.; Gentile, V. The contribution of indirect topographic surveys (photogrammetry and laser scanner) and GPR investigations in the study of the vulnerability of the abbey of Santa Maria a Mare, Tremiti Islands (Italy). Ann. Geophys. 2019, 62, SE343. [CrossRef]

295. Biscarini, C.; Catapano, I.; Cavalagli, N.; Ludeno, G.; Pepe, F.A.; Ubertini, F. UAV Photogrammetry, infrared thermography and GPR for enhancing structural and material degradation evaluation of the Roman masonry bridge of Ponte Lucano in Italy. NDT E Int. 2020, 115, 102287. [CrossRef]

296. De Giorgi, L.; Ferrari, I.; Giuri, F.; Leucci, G.; Scardozzi, G. Integrated geoscientific surveys at the Church of Santa Maria Della Lizza (Alezio, Italy). Sensors 2021, 21, 2205. [CrossRef]

297. Agrafiotis, P.; Lampropoulos, K.; Georgopoulos, A.; Moropoulou, A. 3D modelling the invisible using ground penetrating radar. Int. Arch. Photogramm. Remote Sens. Spatial Inf. Sci. 2017, 42, 33-37. [CrossRef]

298. Ercoli, M.; Brigante, R.; Radicioni, F.; Pauselli, C.; Mazzocca, M.; Centi, G.; Stoppini, A. Inside the polygonal walls of amelia (Central Italy): A multidisciplinary data integration, encompassing geodetic monitoring and geophysical prospections. J. Appl. Geophys. 2016, 127, 31-44. [CrossRef] 
299. Puente, I.; Solla, M.; González-Jorge, H.; Arias, P. NDT documentation and evaluation of the Roman Bridge of Lugo using GPR and mobile and static LiDAR. J. Perform. Constr. Facil. 2015, 29, 06014004. [CrossRef]

300. Solla, M.; Caamano, C.; Riveiro, B.; Lorenzo, H. GPR Analysis of a Masonry Arch for Structural Assessment. In Proceedings of the 2011 6th International Workshop on Advanced Ground Penetrating Radar (IWAGPR), Aachen, Germany, 22-24 June 2011; IEEE: Aachen, Germany, June 2011; p. 5963873. [CrossRef]

301. Arias, P.; Armesto, J.; Di-Capua, D.; González-Drigo, R.; Lorenzo, H.; Pérez-Gracia, V. Digital photogrammetry, GPR and computational analysis of structural damages in a mediaeval bridge. Eng. Fail. Anal. 2007, 14, 1444-1457. [CrossRef]

302. Fauchard, C.; Antoine, R.; Bretar, F.; Lacogne, J.; Fargier, Y.; Maisonnave, C.; Guilbert, V.; Marjerie, P.; Thérain, P.-F.; Dupont, J.-P.; et al. Assessment of an ancient bridge combining geophysical and advanced photogrammetric methods: Application to the Pont De Coq, France. J. Appl. Geophys. 2013, 98, 100-112. [CrossRef]

303. Lubowiecka, I.; Arias, P.; Riveiro, B.; Solla, M. Multidisciplinary approach to the assessment of historic structures based on the case of a Masonry Bridge in Galicia (Spain). Comput. Struct. 2011, 89, 1615-1627. [CrossRef]

304. Lubowiecka, I.; Armesto, J.; Arias, P.; Lorenzo, H. Historic bridge modelling using laser scanning, ground penetrating radar and finite element methods in the context of Structural dynamics. Eng. Struct. 2009, 31, 2667-2676. [CrossRef]

305. Mills, J.P.; Chandler, J.H. Digital photogrammetry, GPR and finite elements in heritage documentation: Geometry and structural damages. Photogramm. Rec. 2007, 22, 94-96. [CrossRef]

306. Riveiro, B.; Arias, P.; Armesto, J.; Caamaño, J.C.; Solla, M. From geometry to diagnosis: Experiences of geomatics in structural engineering. Int. Arch. Photogramm. Remote Sens. Spatial Inf. Sci. 2012, 39, 291-296. [CrossRef]

307. Solla, M.; Caamaño, J.C.; Riveiro, B.; Arias, P. A novel methodology for the structural assessment of stone arches based on geometric data by integration of photogrammetry and ground-penetrating radar. Eng. Struct. 2012, 35, 296-306. [CrossRef]

308. Solla, M.; Lorenzo, H.; Novo, A.; Caamaño, J.C. Structural analysis of the Roman Bibei Bridge (Spain) based on GPR data and numerical modelling. Automat. Constr. 2012, 22, 334-339. [CrossRef]

309. Stavroulaki, M.E.; Riveiro, B.; Drosopoulos, G.A.; Solla, M.; Koutsianitis, P.; Stavroulakis, G.E. Modelling and strength evaluation of masonry bridges using terrestrial photogrammetry and finite elements. Adv. Eng. Softw. 2016, 101, 136-148. [CrossRef]

310. Santos-Asssunçao, S.; Perez-Gracia, V.; Gonzalez, R.; Caselles, O.; Clapes, J.; Salinas, V. Geophysical exploration of columns in historical heritage buildings. In Proceedings of the 15th International Conference on Ground Penetrating Radar, Brussels, Belgian, 30 June-4 July 2014; IEEE: Belgian, Brussels, 2014; pp. 97-102.

311. Santos-Assunçao, S.; Perez-Gracia, V.; Caselles, O.; Clapes, J.; Salinas, V. Assessment of complex masonry structures with GPR compared to other non-destructive testing studies. Remote Sens. 2014, 6, 8220-8237. [CrossRef]

312. Merkle, D.; Frey, C.; Reiterer, A. Fusion of ground penetrating radar and laser scanning for infrastructure mapping. J. Appl. Geodesy 2021, 15, 31-45. [CrossRef]

313. Bianchi, M.G.; Casula, G.; Cuccuru, F.; Fais, S.; Ligas, P.; Ferrara, C. Three-dimensional imaging from laser scanner, photogrammetric and acoustic non-destructive techniques in the characterization of stone building materials. Adv. Geosci. 2018, 45, 57-62. [CrossRef]

314. Casula, G.; Cuccuru, F.; Bianchi, M.G.; Fais, S.; Ligas, P. High resolution 3-D modelling of cylinder shape bodies applied to ancient columns of a church. Adv. Geosci. 2020, 54, 119-127. [CrossRef]

315. Apollonio, F.I.; Gaiani, M.; Sun, Z. A reality integrated BIM for architectural heritage conservation. In Handbook of Research on Emerging Technologies for Architectural and Archaeological Heritage; Advances in Religious and Cultural Studies; Ippolito, A., Ed.; IGI Global: Hershey, PA, USA, 2017; ISBN 978-1-5225-0675-1.

316. Alshawabkeh, Y.; Baik, A.; Miky, Y. Integration of laser scanner and photogrammetry for heritage BIM enhancement. IJGI 2021, 10, 316. [CrossRef]

317. Godinho, M.; Machete, R.; Ponte, M.; Falcão, A.P.; Gonçalves, A.B.; Bento, R. BIM as a resource in heritage management: An application for the national palace of Sintra, Portugal. J. Cult. Herit. 2020, 43, 153-162. [CrossRef]

318. Solla, M.; Gonçalves, L.M.S.; Gonçalves, G.; Francisco, C.; Puente, I.; Providência, P.; Gaspar, F.; Rodrigues, H. A building information modeling approach to integrate geomatic data for the documentation and preservation of cultural heritage. Remote Sens. 2020, 12, 4028. [CrossRef]

319. Tsilimantou, E.; Delegou, E.T.; Nikitakos, I.A.; Ioannidis, C.; Moropoulou, A. GIS and BIM as integrated digital environments for modeling and monitoring of historic buildings. Appl. Sci. 2020, 10, 1078. [CrossRef]

320. Martín-Lerones, P.; Olmedo, D.; López-Vidal, A.; Gómez-García-Bermejo, J.; Zalama, E. BIM supported surveying and imaging combination for heritage conservation. Remote Sens. 2021, 13, 1584. [CrossRef]

321. Adamopoulos, E.; Rinaudo, F. UAS-based archaeological remote sensing: Review, meta-analysis and state-of-the-art. Drones 2020, 4, 46. [CrossRef]

322. Campana, S. Drones in archaeology. State-of-the-art and future perspectives: Drones in archaeology. Archaeol. Prospect. 2017, 24, 275-296. [CrossRef]

323. Azzola, P.; Cardaci, A.; Mirabella Roberti, G.; Nannei, V.M. UAV Photogrammetry for cultural heritage preservation modeling and mapping Venetian Walls of Bergamo. Int. Arch. Photogramm. Remote Sens. Spatial Inf. Sci. 2019, 42, 45-50. [CrossRef]

324. Bakirman, T.; Bayram, B.; Akpinar, B.; Karabulut, M.F.; Bayrak, O.C.; Yigitoglu, A.; Seker, D.Z. Implementation of ultra-light UAV systems for cultural heritage documentation. J. Cult. Herit. 2020, 44, 174-184. [CrossRef] 
325. Mirabella Roberti, G.; Nannei, V.M.; Azzola, P.; Cardaci, A. Preserving the Venetian fortress of Bergamo: Quick photogrammetric survey for conservation planning. Int. Arch. Photogramm. Remote Sens. Spatial Inf. Sci. 2019, 42, 873-879. [CrossRef]

326. Mohd Nasir, N.H.; Tahar, K.N. 3D model generation from UAV: Historical mosque (Masjid Lama Nilai). Int. Arch. Photogramm. Remote Sens. Spatial Inf. Sci. 2017, 42, 251-255. [CrossRef]

327. Pepe, M.; Costantino, D. UAV Photogrammetry and 3D modelling of complex architecture for maintenance purposes: The case study of the masonry bridge on the Sele River, Italy. Period. Polytech. Civil Eng. 2020. [CrossRef]

328. Suwardhi, D.; Menna, F.; Remondino, F.; Hanke, K.; Akmalia, R. Digital 3D borobudur-Integration of 3D surveying and modeling techniques. Int. Arch. Photogramm. Remote Sens. Spatial Inf. Sci. 2015, 40, 417-423. [CrossRef]

329. Themistocleous, K.; Mettas, C.; Evagorou, E.; Hadjimitsis, D.G. The use of UAVs and photogrammetry for the documentation of cultural heritage monuments: The case study of the Churches in Cyprus. In Proc. SPIE 11156, Proceedings of the Earth Resources and Environmental Remote Sensing/GIS Applications X, Strasbourg, France, 10-12 September 2012; Schulz, K., Nikolakopoulos, K.G., Michel, U., Eds.; SPIE: Strasbourg, France, 2019; p. 111560.

330. Grenzdörffer, G.J.; Naumann, M.; Niemeyer, F.; Frank, A. Symbiosis of UAS photogrammetry and TLS for surveying and 3D modeling of cultural heritage monuments-A case study about the Cathedral of St. Nicholas in the City of Greifswald. Int. Arch. Photogramm. Remote Sens. Spatial Inf. Sci. 2015, 40, 91-96. [CrossRef]

331. Hua, W.; Qiao, Y.; Hou, M. The great wall 3D documentation and application based on multi-source data fusion-A case study of No.15 enemy tower of the new guangwu great wall. Int. Arch. Photogramm. Remote Sens. Spatial Inf. Sci. 2020, 43, 1465-1470. [CrossRef]

332. Luhmann, T.; Chizhova, M.; Gorkovchuk, D. Fusion of UAV and terrestrial photogrammetry with laser scanning for 3D reconstruction of historic churches in georgia. Drones 2020, 4, 53. [CrossRef]

333. Parrinello, S.; Marco, R.D. Integration and modelling of 3D data as strategy for structural diagnosis in endangered sites. The study case of Church of the Annunciation in Pokcha (Russia). In Proceedings of the 2019 IMEKO TC-4 International Conference on Metrology for Archaeology and Cultural Heritage (2019 MetroArchaeo), Florence, Italy, 4-6 December 2019; Catelani, M., Daponte, P., Eds.; IMEKO: Florence, Italy, 2019; pp. 223-228. Available online: https://www.imeko.org/publications/tc4 -Archaeo-2019/IMEKO-TC4-METROARCHAEO-2019-41.pdf (accessed on 27 September 2021).

334. Rabbia, A.; Sammartano, G.; Spanò, A. Fostering etruscan heritage with effective integration of UAV, TLS and SLAM-based methods. In Proceedings of the 2020 IMEKO TC-4 International Conference on Metrology for Archaeology and Cultural Heritage (2020 MetroArchaeo), Trento, Italy, 22-24 October 2020; Daponte, P., Gialanella, S., Petri, D., Eds.; IMEKO: Trento, Italy, 2020; pp. 322-327. Available online: https:/ / www.imeko.org/publications/tc4-Archaeo-2020/IMEKO-TC4-MetroArchaeo2020-060.pdf (accessed on 27 September 2021).

335. Teppati Losè, L.; Chiabrando, F.; Giulio Tonolo, F. Documentation of complex environments using $360^{\circ}$ cameras. The Santa Marta Belltower in Montanaro. Remote Sens. 2021, 13, 3633. [CrossRef]

336. Deng, F.; Zhu, X.; Li, X.; Li, M. 3D digitisation of large-scale unstructured great wall heritage sites by a small unmanned helicopter. Remote Sens. 2017, 9, 423. [CrossRef]

337. Alsadik, B.; Remondino, F. Flight planning for LiDAR-based UAS mapping applications. ISPRS Int. J. Geoinf. 2020, 9, 378. [CrossRef]

338. Marino, B.G.; Masiero, A.; Chiabrando, F.; Lingua, A.M.; Fissore, F.; Błaszczak-Bak, W.; Vettore, A. Data optimization for 3D modeling and analysis of a fortress architecture. Int. Arch. Photogramm. Remote Sens. Spatial Inf. Sci. 2019, 42, 809-813. [CrossRef]

339. Previtali, M.; Stanga, C.; Molnar, T.; Van Meerbeek, L.; Barazzetti, L. An integrated approach for threat assessment and damage identification on built heritage in climate-sensitive territories: The Albenga case study (San Clemente Church). Appl. Geomat. 2018, 10, 485-499. [CrossRef]

340. Grilli, E.; Menna, F.; Remondino, F. A review of point clouds segmentation and classification algorithms. Int. Arch. Photogramm. Remote Sens. Spatial Inf. Sci. 2017, 42, 339-344. [CrossRef]

341. Grilli, E.; Remondino, F. Classification of 3D digital heritage. Remote Sens. 2019, 11, 847. [CrossRef]

342. Matrone, F.; Grilli, E.; Martini, M.; Paolanti, M.; Pierdicca, R.; Remondino, F. Comparing machine and deep learning methods for large 3D heritage semantic segmentation. ISPRS Int. J. Geoinf. 2020, 9, 535. [CrossRef]

343. Croce, V.; Caroti, G.; De Luca, L.; Jacquot, K.; Piemonte, A.; Véron, P. From the semantic point cloud to heritage-building information modeling: A semiautomatic approach exploiting machine learning. Remote Sens. 2021, 13, 461. [CrossRef]

344. Templin, T.; Popielarczyk, D. The use of low-cost unmanned aerial vehicles in the process of building models for cultural Tourism, 3D web and augmented/mixed reality applications. Sensors 2020, 20, 5457. [CrossRef]

345. Calantropio, A.; Chiabrando, F.; Sammartano, G.; Spanò, A.; Teppati Losè, L. UAV Strategies validation and remote sensing data for damage assessment in post-disaster scenarios. Int. Arch. Photogramm. Remote Sens. Spatial Inf. Sci. 2018, 42, 121-128. [CrossRef]

346. Chiabrando, F.; Di Lolli, A.; Patrucco, G.; Spanò, A.; Sammartano, G.; Teppati Losè, L. Multitemporal 3D modelling for cultural heritage emergency during seismic events:damage assesment of S. Agostino Church in Amatrice (RI). Int. Arch. Photogramm. Remote Sens. Spatial Inf. Sci. 2017, 42, 69-76. [CrossRef]

347. Achille, C.; Adami, A.; Chiarini, S.; Cremonesi, S.; Fassi, F.; Fregonese, L.; Taffurelli, L. UAV-based photogrammetry and integrated technologies for architectural applications-Methodological strategies for the after-quake survey of vertical structures in Mantua (Italy). Sensors 2015, 15, 15520-15539. [CrossRef] [PubMed] 
348. Baranwal, E.; Seth, P.; Pande, H.; Raghavendra, S.; Kushwaha, S.K.P. Application of unmanned aerial vehicle (UAV) for damage assessment of a cultural heritage monument. In Proceedings of the UASG 2019, Roorkee, India, 6-7 April 2019; Lecture Notes in Civil Engineering. Jain, K., Khoshelham, K., Zhu, X., Tiwari, A., Eds.; Springer International Publishing: Cham, Switzerland, 2020; Volume 51, pp. 123-131, ISBN 978-3-030-37392-4.

349. Baranwal, E.; Raghvendra, S.; Tiwari, P.S.; Pande, H. Health monitoring and assessment of the cultural monument through unmanned aerial vehicle (UAV) image processing. In Advances in Systems Engineering; Lecture Notes in Mechanical Engineering; Saran, V.H., Misra, R.K., Eds.; Springer: Singapore, 2021; pp. 145-160, ISBN 9789811580246.

350. Pepi, C.; Cavalagli, N.; Gusella, V.; Gioffrè, M. An integrated approach for the numerical modeling of severely damaged historic structures: Application to a Masonry Bridge. Adv. Eng. Softw. 2021, 151, 102935. [CrossRef] 